Article

\title{
Evaluation of the Integration of the Traditional Architectural Element Mashrabiya into the Ventilation Strategy for Buildings in Hot Climates
}

\author{
Abdullah Abdulhameed Bagasi ${ }^{1,2, *}$, John Kaiser Calautit ${ }^{2}(1)$ and Abdullah Saeed Karban ${ }^{1}$ \\ 1 Department of Islamic Architecture, Umm Al-Qura University, P.O. Box 715, Makkah, Saudi Arabia; \\ Askarban@uqu.edu.sa \\ 2 Department of Architecture and Built Environment, University of Nottingham, Nottingham NG7 2RD, UK; \\ John.calautit1@nottingham.ac.uk \\ * Correspondence: Aabagasi@uqu.edu.sa; Tel.: +966-5555-63252
}

Citation: Bagasi, A.A.; Calautit, J.K.; Karban, A.S. Evaluation of the Integration of the Traditional Architectural Element Mashrabiya into the Ventilation Strategy for Buildings in Hot Climates. Energies 2021, 14, 530. https://doi.org/ 10.3390/en14030530

Academic Editor: Poul

Alberg Østergaard

Received: 7 December 2020

Accepted: 14 January 2021

Published: 20 January 2021

Publisher's Note: MDPI stays neutral with regard to jurisdictional claims in published maps and institutional affiliations.

Copyright: (C) 2021 by the authors. Licensee MDPI, Basel, Switzerland. This article is an open access article distributed under the terms and conditions of the Creative Commons Attribution (CC BY) license (https:// creativecommons.org/licenses/by/ $4.0 /)$.

\begin{abstract}
This paper reviewed related research works and developments on the traditional architectural element "mashrabiya" focusing on its history, design and structure, typology, and functions in hot climates. Moreover, the paper assessed the effect of the traditional mashrabiya on the indoor thermal environment and thermal comfort in a selected case study building. For this purpose, two similar rooms were investigated in a selected historic building with abundant mashrabiyas located in the Makkah Region, specifically in Old Jeddah, Saudi Arabia. The field tests were conducted during a typical hot summer month with two different configurations. The study demonstrated that opening the mashrabiya allowed more airflow into the room during the day and reduced the indoor temperature by up to $2.4^{\circ} \mathrm{C}$ as compared to the closed mashrabiya. Besides, the building envelope played an important role in preventing the high fluctuation of the indoor air temperature, where the fluctuation of the rooms air temperature ranged between $2.1{ }^{\circ} \mathrm{C}$ and $4.2{ }^{\circ} \mathrm{C}$ compared to the outdoor temperature which recorded a fluctuation between $9.4^{\circ} \mathrm{C}$ and $16^{\circ} \mathrm{C}$. The data presented here can be used for the future development of the mashrabiya concept and the potential incorporation with passive cooling methods to improve its design according to the requirements of modern buildings in hot climates. Moreover, further studies and tests on mashrabiyas under different climatic conditions are required. Also, the different strategies or materials can be incorporated with mashrabiyas in order to improve its thermal performance.
\end{abstract}

Keywords: mashrabiya; roshan; thermal performance; thermal mass; passive ventilation; thermal comfort; daylight; indoor thermal environment; Saudi Arabia

\section{Introduction}

The accelerated development of Saudi Arabia during the last decades led to major changes in the economic, social, and buildings fields and experienced a high increase in energy demand. The high temperatures throughout the year in Saudi Arabia make cooling systems a necessity to achieve human comfort [1]. In general, a large portion of energy is consumed globally to keep the indoor air temperature of buildings within the required comfort temperature [2].

For a hundred years, several architectural elements were employed effectively and widely on the traditional housing in the Arab Gulf region such as mashrabiyas, courtyards, and windcatchers that have demonstrated to meet the needs of the population and have strong local climate compatibility.

In a number of old cities in the Middle East such as Jeddah, Makkah, Yanbu, Baghdad, Cairo, Damascus, and Tunis, mashrbabiyas still exist as one of the most prominent traditional architectural elements [3]. Mashrabiyas have also been found and adopted widely in different countries around the world from the Far East to South America such as India, Japan, China, Portugal, and Spain. 
A mashrabiya was described by Fathy [4] as a space covered in cantilevers with a wooden grid, in which small jars of water were positioned to cool the air through the apertures by the influence of evaporation. It can also be defined as a wooden frame covering a window opening and decorating the building façade. Mashrabiyas are traditionally characterised by their functions, allowing air and daylight to penetrate and providing privacy beside the aesthetic purpose (Figure 1).

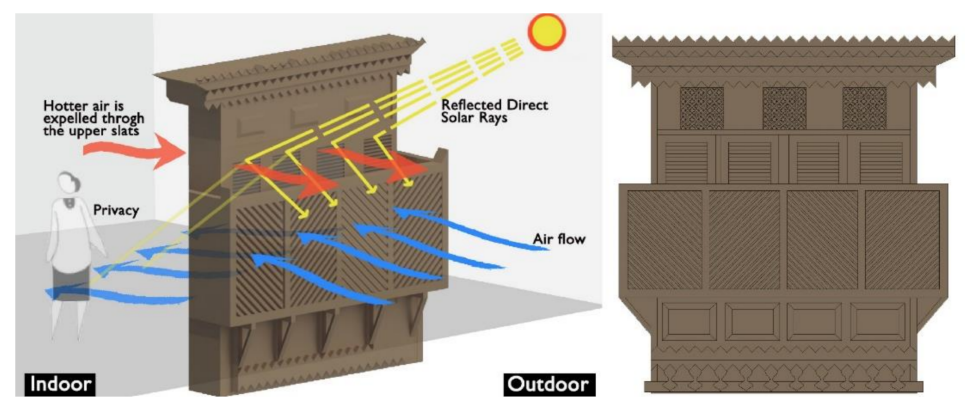

Figure 1. Example of Mashrabiya demonstrating the principal functions. Reproduced from Bagasi and Calautit [3].

The building's thermal mass plays an important part in enhancing thermal efficiency in hot climates alongside the function of the mashrabiya. In warm seasons, walls and floors absorb heat on their surfaces, conducted internally and emitted as the air gets colder at night $[5,6]$. Ventilation at night through a mashrabiya can minimise the cooling load in buildings [7]. Furthermore, high thermal masses like heavy bricks and stones can effectively reduce temperature variations within a space over time [8].

In the past decades, many researchers have studied various aspects of mashrabiyas. As far as we know, most studies tend to focus on either their history or on developing mashrabiyas without testing or considering the actual performance and influence on the indoor thermal environment.

Therefore, this study aims to review mashrabiyas and related research work and developments from the environmental side in residential buildings in hot climates. Also, assess the effect of traditional mashrabiyas on the indoor thermal environment in a residential building in hot climates. The work also assesses the effect of thermal mass and evaluates the effectiveness of the mashrabiya in achieving thermal comfort.

Overall, the paper presents an overview of the mashrabiya; its history, functions, structure and design, and related research works as well as the most prominent applications and developments. Furthermore, a case study building with mashrabiyas located in a hot climate was selected and tested.

\section{Traditional Mashrabiya}

A mashrabiya can be defined as a wooden frame covering a window opening and decorating the building facade. Mashrabiyas is known under different names based on the reign, it is known as shanasheel in Iraq and Iran, mushabak in Iran [9], roshan in Sudan, takhrima means "full of holes" in Yemen, and moucharabieh in Algeria [10]. While in Saudi Arabia, mashrabiya is called either mashrabiya or roshan.

The word "mashrabiya" is of Arabic origin, but there are some differences in the interpretation of its source. Mashrabiya in Arabic is derived from mashrabah, meaning the place from which to drink [11]. In another interpretation mashrabiya linguistically takes its origin from "mashrafiya" the noun of the verb "ashrafa" which means the place to look out or observe from the upper level $[12,13]$. With time and as a result of the accents and effect of the non-Arab speakers, mashrafiya became the uttering mashrabiya [10]. On the other hand, Fathy [4] said that the word mashrabiya originates from the Arabic word 'sharbah' meaning "drink" and originally referring to "a drinking place". He also mentioned that the word (mashrabiya) came to refer to a wooden grid screen with circular balustrades that 
are partially small and arranged in regular spaces delineated by an intricate decorative geometric pattern. Mashrabiyas were defined by Kamal [14] as "projecting windows with wooden latticework for natural ventilation and privacy".

\subsection{History of Mashrabiya}

When and where mashrabiyas originated thus cannot be confirmed, due to the conflicting researchers' opinions. The following is a brief review of some researchers' statements about the emergence of the mashrabiya. Khan [15] stated that the origins of mashrabiya might date back to the ancient castles or forts of the past that were built with distinctive bay windows that were used for defensive purposes by casting hot water or oil on the enemies below through small openings in the bottom of the bay [16]. Khan [15] also added that mashrabiyas were known and dominant in the Islamic world architecture during the Mamluk and Ottoman eras. Sudy [17] mentioned that the mashrabiya was created in the thirteenth century AD, where it was developed by Muslim builders during the Mamluk Era in Cairo. Abdelgelil [18] stated the mashrabiya first appeared in Egypt (1517-1905) during the Mamluk and Ottoman periods. During the Mamluk rule era (1248-1516), mashrabiya were a predominant architectural element where maybe the oldest mashrabiya can be found in the Great Masjid at Qayrawan [19]. Alitany et al. [20] mentioned: "The term roshan can be traced as far back as $1100 \mathrm{AD}$ and in North Africa, Egypt and Yemen has come to be known as mashrabiya". In the Ottoman era, the mashrabiya reached the climax of its spread and widely used across almost the entirety of Iraq, Syria, Egypt and the Arabian Peninsula.

In the western region of Saudi Arabia, Jeddah has played a vital and significant role as a gateway for pilgrims due to its seaport which is near the holiest cities Makkah and Medina. Thus, these cities benefited from the exchange of cultures with the caravans of the Hajj pilgrimage, which came from different countries bringing their skills, exchanging ideas with the domestic people and enriching the architectural art, including the mashrabiyas in Hijaz [21].

However, the mashrabiya "interlaced wooden screen" is not limited to Arab countries, but rather exists and has been adopted in numerous regions around the world ranging from the Far East to South America. As a result, mashrabiya has several names and variations in spelling (Figure 2). For example, in India, it is called "Jali, Jaali, Jaalis, or Jalis", which means the latticework screen.

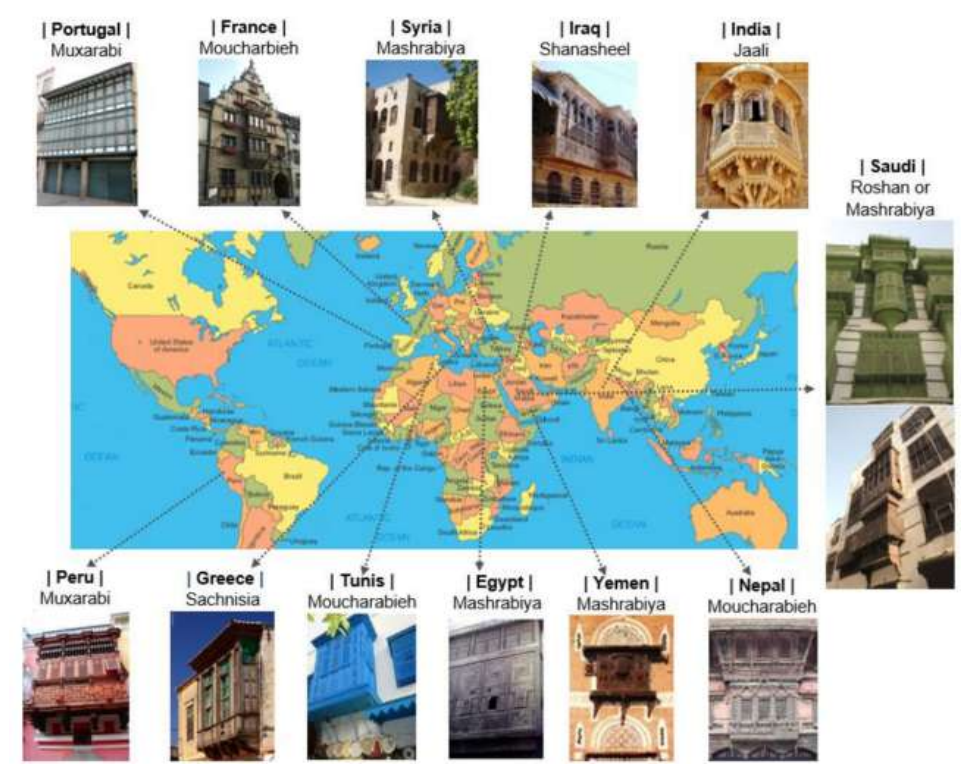

Figure 2. Traditional Mashrabiya around the world and its local names. 


\subsection{Mashrabiya Design and Structure Details}

Mashrabiya designs vary from region to region depending on several physical variables. These variables can be its size, construction material, patterns and ornamentation, and openings. The most influencing factors affecting the performance of the mashrabiyas are their shape, apertures and projection.

Moreover, the regular construction material used in the mashrabiya structure is wood. Many types of wood are used for these structures, but the most common ones used in Saudi Arabia are teak, ebony, oak and mahogany [16]. Another material historically used in some countries such as Iran and India for structured latticed screens is so-called "terracotta" [22].

Mostly, the structure of a mashrabiya comprises three major parts: the upper, middle, and the lower part. Each part has several components that are either functional, aesthetic or both. Alitany; et al. [23] defined these parts as the head "crown or tajj", the body "suddir", and the base "qaida" (Figure 3). Al-Shareef [16] described the division of the external details of mashrabiyas into five elements: crown, first horizontal panel, opening sashes, second horizontal panel and brackets. In addition, there are some other elements that can be adopted as additions based on the prevailing climate such as wooden screens (sheesh) and water jars [16].

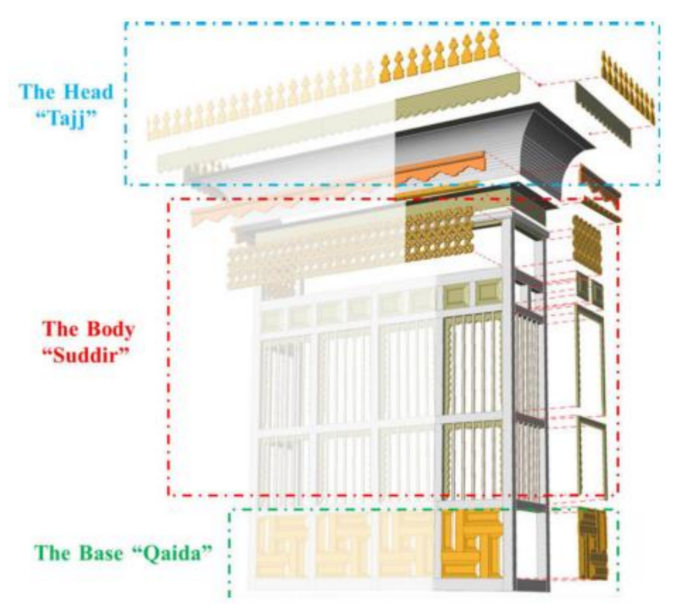

Figure 3. Main parts of a mashrabiya in Jeddah. Reproduced from Alitany et al. [23].

Typical mashrabiya parts can be divided broadly into three main structural components - the head, the body, and the base - each with several elements (Figure 4). The crown in the upper part work as a canopy for the middle part of the mashrabiya, while the pearl is in the middle of the crown. The upper belt connects the upper part with the middle part. Under the upper belt, the sashes are in the middle part of mashrabiya that can be designed as louvres, shutters, or screens [24]. The sashes are considered the essential part due to their significant role in most of the mashrabiya's functions for allowing penetrating air and daylight and providing privacy.

The sashes cover an aperture and usually divided horizontally into two equal sections. Vertically, the middle part usually contains three to five sashes. Each sash has several horizontal sliding slats or "louvre blades" [25]. The primary purpose of movable louvres is to control the entry of light and air into a room as desired by the occupant [19]. Over the lower sashes with a overhang of $0.5 \mathrm{~m}$ from the external part, a wooden screen locally named "sheesh" was placed in some mashrabiyas where it provides a place for water jars, which work to cool the air by evaporation [25]. The bottom part of a mashrabiya consists of two sections: the lower belt and brackets. The brackets work as the main support of the whole mashrabiya structure. 


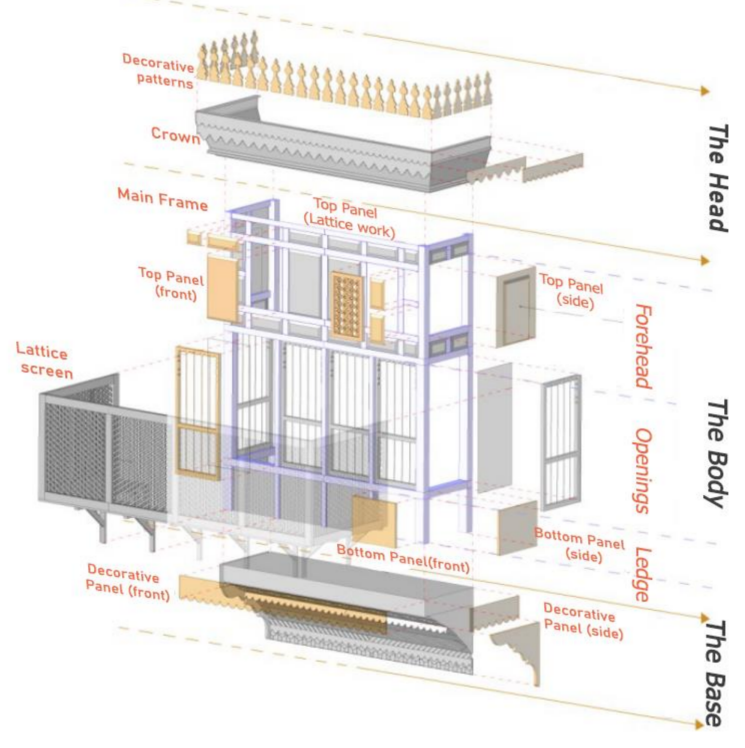

Figure 4. Detailed view of parts and components for a mashrabiya in Jeddah, amended from Alitany et al. [20].

\subsection{Mashrabiya Typology}

Mashrabiyas differ in their forms from one region to another due to several factors. These differences were mainly due to the climate type, the skill of the local craftsmen, the accuracy of the details and the woodwork, and depend on the client's request and financial ability. An abundance of inscriptions and an increase in detailing details and the size of a mashrabiya and the quality of the wood used in its construction are indicative of the wealth and social status of the owner of the house.

Salloum [26] divided the mashrabiya into three sorts taking into consideration the size: (1) simple wooden screens or louvres covering the openings; (2) the cantilevered mashrabiya as an expansion part of the interior spaces; (3) wooden louvres on two or three sides surrounding a room located on the uppermost floor of a property named "al mabit" where the occupants sleep during hot days. Aljofi [27] also divided the mashrabiya into three types: (1) cantilevered, (2) screen panels, (3) louvred timber walls and louvred windows. In Jeddah, mashrabiya come in many different shapes and sizes; the most common shapes can be classified into three groups: mashrabiyas, plain mashrabiyas, and projected mashrabiya, as shown in Figure 5.

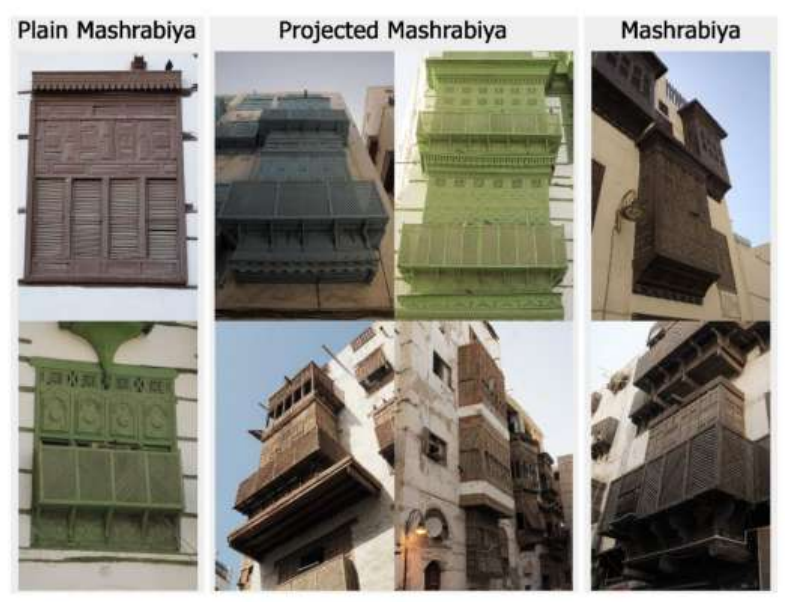

Figure 5. Different shapes of Mashrabiya in Historic Jeddah. 


\subsection{Dimensions}

Due to the different shapes and sizes of mashrabiyas, there have no fixed size. However, some researchers have outlined the typical dimensions of mashrabiyas. Greenlaw [28] described the main internal dimensions of the traditional mashrabiya by saying: "The size of a roshan is related to the dimensions of the human body; it is wide enough to lie down in comfortably, that is just over two meters, $2.40 \mathrm{~m}$ usually; high enough to stand in, about $3 \mathrm{~m}$, and projecting about $60 \mathrm{~cm}$ into the street". A typical mashrabiya was described by Alitany et al. [23] and Adas [29]. Its width is $2.4-2.8 \mathrm{~m}$ and its internal height $2.7-3.5 \mathrm{~m}$. It can protrude externally about $0.4-0.7 \mathrm{~m}$. By adding the thickness of the external wall with the projection of the Mashrabiya, it may result in a width that ranges up to $1.2 \mathrm{~m}$, and this can be conveniently used as a seating area. Hariri [30] stated the floor of a mashrabiya was either an extension of the floor of the room or higher than a floor level by around $0.5 \mathrm{~m}$. Al-Shareef [16] stated, "The usual dimensions of a single traditional roshan unit are $3 \mathrm{~m}$ in height, $2.3 \mathrm{~m}$ in width and 1.1-1.9 $\mathrm{m}$ in depth, to allow sufficient space for a sleeping adult. Some roshans are built with a depth of $1.9 \mathrm{~m}$ to accommodate a man and his wife".

\section{Functions of Mashrabiya}

Although mashrabiya were widely used in many different countries, they generally have the same functions. Functionally, a mashrabiya is primarily focused on environmental, social and architectural factors. Mashrabiya perfectly works as a protection device from direct sunlight and effectively reduces heat gain, especially during hot seasons. Traditional mashrabiyas are durabke and do not need frequent maintenance where excellent quality wood types are used in the mashrabiya, such as teak or mahogany wood, which are durable and can be used for long periods without damage and resist extreme weather conditions such as heat and humidity [30]. According to the architect Hassan Fathy "The mashrabiya interstices both intercept the direct solar radiation and soften the uncomfortable glare. Besides, considering that the mashrabiya is made of out wood, it helps regulate the humidity inside the space. It is known that wood absorbs, retains and releases water. When air passes through the interstices of the porous wooden mashrabiya, it vaporises some of the moisture gathered in the wood and carries it towards the interior" [31]. Sabry and Dwidar [32] stated that "Mashrabia provide shade within the housing without complete closure of windows and allow the movement of air, which helps to reduce the temperature in the summer". Algburi and Beyhan [33] mentioned that the lattice apertures on mashrabiya surfaces allow the passage of natural fresh air and hence provide thermal comfort. Mashrabiyas work perfectly for social life in houses. They provide privacy to room occupants and grants them freedom in their actions and movements. At the same time, it allows looking outward without isolation from the surrounding environment.

Aestheticism is another important function of the mashrabiya, as its shapes and designs adorn houses' facades. Mashrabiyas generally are characterised by an aesthetic shape and precision geometric and beauty with ornamental inscriptions of different styles. Besides, the mashrabiya's outline and parts are in line with the vertical extension of the façades, which directly contribute to making the functions of mashrabiya efficient. Al-Ban [34] noted that the colours, lattice works, motifs and facades of Mashrabiyas contributed to creating a distinctive visual character in Jeddah. The mashrabiya and its carved wood openings foster a unique dialogue between the interior and the exterior while creating a beautiful and pleasant link between privacy and publicity for the home [34]. Moreover, Ashour [35] said: "Regarding psychological needs, one can investigate how the mashrabiya enhances the feelings of confidence, bliss, and quiet relaxation experienced by the occupants and how much it arouses and inspires creative energy".

\section{Mashrabiya Status}

With the rapid development in the past decades, climate change and increasing humanitarian needs, some issues have emerged in the use of mashrabiya. Due to the perimeter of adjustable louvres, it is not possible to close Mashrabiya tightly. The louvres need a slid- 
ing path, and as they go down,the friction with the wood increase, and flipping is neither possible nor difficult. All of that can lead to dust permeability and penetration of insects, including noise disturbance [30]. In addition, continuous air leakage is not compatible with one of the essential needs of modern houses in Saudi Arabia (air conditioning), which depends on the isolation of external air to control the internal air temperature effectively and economically.

Moreover, the cost of the mashrabiya is several times higher than that of regular windows made of wood or aluminium. Batterjee [24] mentioned that "Roshan is made from expensive woods such as teak, ebony, oak, and mahogany. These woods are difficult to find locally and expensive to import. That raises the cost of construction and maintenance considerably". In addition to that, the period required to implement a mashrabiya is long where the manufacture and installation of one mashrabiya may take up to two months or more based on the size and design.

Otusanya, et al. [36] stated "New passive cooling technologies are being discovered every day, but undeniably the internal thermal comfort of buildings cannot be attained utilising only one passive cooling method". Also, new technologies such as fans and air conditioners provide alternative solutions that address the drawbacks of mashrabiyas. These technologies have replaced the majority of mashrabiyas' essential functions, such as natural ventilation and cold air, as faster and more active efficiency to meet thermal needs in the hot climates. [37]. However, in view of the need to reduce the emissions of greenhouse gases, passive techniques should be applied in buildings and integrated with active techniques [38]. Alothman [39] stated that air conditioners have failed in some way compared to mashrabiyas, due to the fact they require a lot of energy and are expensive to run.

\subsection{Previous Studies on Traditional Mashrabiya}

Since several studies have studied different aspects of mashrabiyas, in the following section we will review and discuss some related studies, especially concerning ventilation, daylight, and integration with passive evaporative cooling. In 1996, Al-Shareef studied the mashrabiya as an element to control daylight for energy conservation in tropical architecture considering the Hejaz architecture used in the west of Saudi Arabia as a case study. The type of mashrabiya considered consists of movable horizontal louvres in eight sashes arranged in several columns and rows. The sashes were tested with slat declination angles of $30^{\circ}, 45^{\circ}$ and $60^{\circ}$. Al-Shareef concluded that the flat mashrabiya produces very high internal illuminance compared to the projected one, and as the mashrabiya's size is increased, the illuminance increases too. Also, adjustment of the slat declination angles plays a significant role in the level and distribution of illuminance on the work surface [16].

In 2002, Maghrabi [25] studied modulated louver windows with reference to Jeddah's mashrabiyas to examine the ventilation efficiency through modeling and simulation. The study revealed that the main reasons for poor ventilation in the rooms were when the slides were adjusted in an acute inclination position. Also, the ventilation openings and free space in the mashrabiya were affected with the slats tilted to $\pm 60^{\circ}$ resulting in a decrease in the main pressure. Maghrabi stated that the form of the mashrabiya played an important role in the flow pattern inside the room since the flat mashrabiya allowed more airflow in its centre compared to prominent mashrabiyas. In addition, in Jeddah the best option was to use windows near the roof, which increases airflow near the floor and makes the atmosphere at home more comfortable.

According to Aljofi [27] "Orientation, times of the day play an important role in the amount of lighting passing the mashrabiya". In 2005, Aljofi tested six screen panels of different regular shapes. The illumination values of rounded screen cells were the lowest in comparison with other screen panel types.Compared to the dark oak wood screen, the light oak contributed more light by an average DF of $17 \%$. Besides, it was found as the diameter of the screen cell increases the reflected light increases too. Al-Hashimi and Semidor [40] studied mashrabiyas' effects on daylight values in Jeddah's residential buildings. The 
study examined a room with a wooden mashrabiya as shown in Figure 6. Three design cases were examined: a room with main openings closed by Venetian blinds, a room with open openings, and a room with a single glazed window facing north during daytime [40]. The study found the most massive daylight value during daytime corresponded to a mashrabiya with a opened Venetian blind. Although the space with a closed Venetian was dark, some small quantity of daylight $(<1 \%)$ always enters from the top of mashrabiya. In 2020, Alwetaishi, et al. [41] investigated the thermal comfort in a historical building with mashrabiya located in Taif (Saudi Arabia). The study used an evaporative cooling technique to enhance the thermal comfort by increasing the indoor airspeed. It was found that the "evaporative cooling technique has a considerable impact on reducing indoor air temperature with a $4{ }^{\circ} \mathrm{C}$ drop, improving the thermal comfort sensation level" [41].
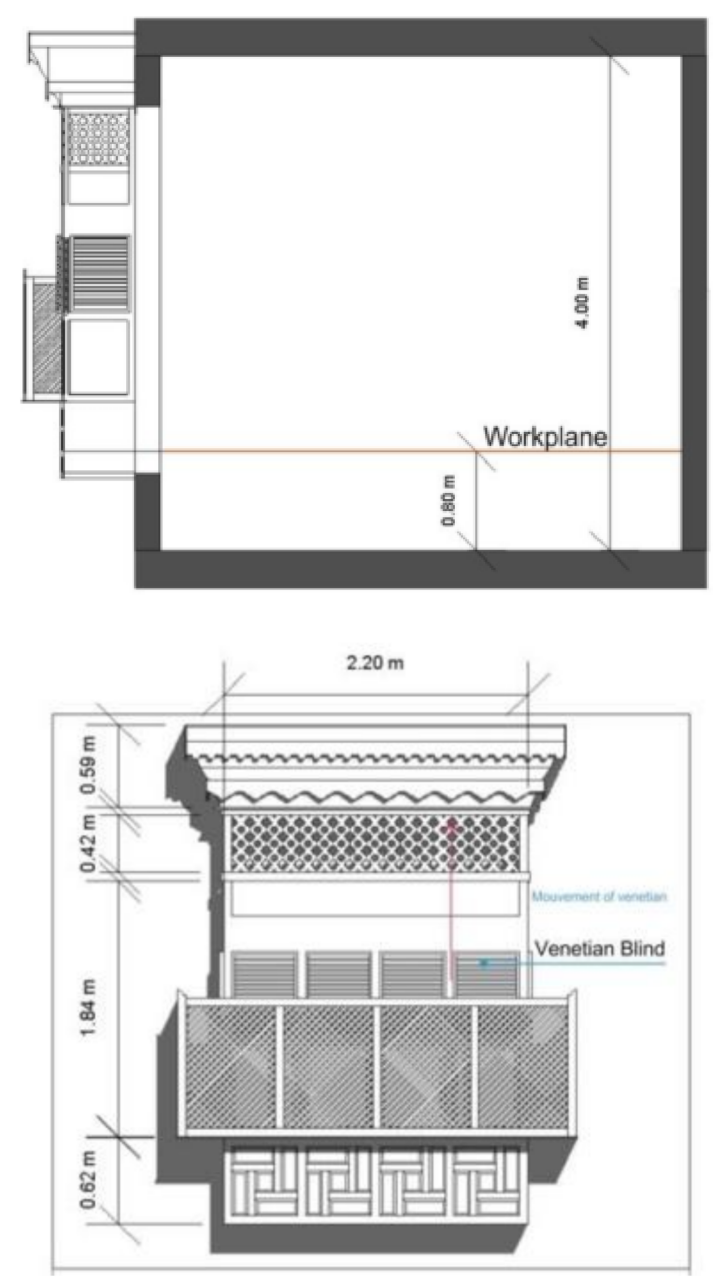

Figure 6. The evaluated room and mashrabiya dimensions. Reproduced from Al-Hashimi and Semidor [40].

\subsection{Contemporary Mashrabiya "Mashrabiya Development"}

In the current era, various shapes derived from mashrabiya can be found on the façades of buildings in various countries around the world. Also, several studies and applications have submitted new designs or proposals for the development of mashrabiya either using different materials instead of wood such as aluminium, steel, ceramic, or glass fibre reinforced concrete (GRC), incorporating interactive techniques for opening and closing, or with integration of evaporative cooling systems in an attempt to boost the indoor thermal and energy consumption conditions. In 2010, Batterjee proposed a solution for a mashrabiya in Jeddah by developing its daylight penetration performance and decreasing the energy consumption. Batterjee designed five models with different parameters 
and examined the daylight levels using Ecotect and Radiance software (Figure 7). The dimensions of the mashrabiya models were $2.4 \mathrm{~m}(\mathrm{w}) \times 3 \mathrm{~m}(\mathrm{~h}) \times 0.4 \mathrm{~m}$ (prominent depth). The best case was a designed $10 \mathrm{~cm} \times 10 \mathrm{~cm}$ opening tilted $45^{\circ}$ upward on the interior side using stainless steel and double low-E glazing with an aluminium frame. This reduced the cooling load by up to $49 \%$ and proved to be the best overall solution suggested except for the east orientation due to the low position of the Sun during that period.

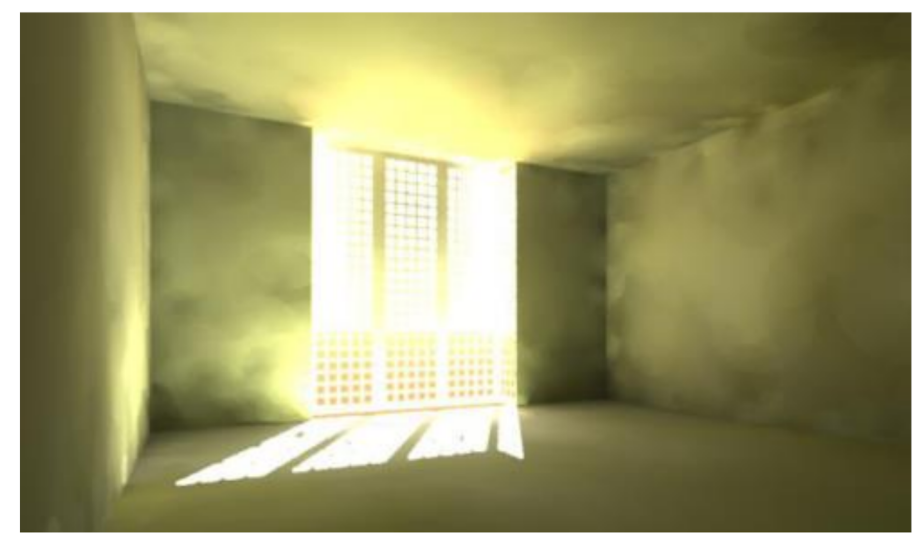

Figure 7. Simulation via Radiance for evaluating lighting level. Reproduced from Batterjee [24].

Benedetti et al. [42] investigated the evaporative cooling potential of mashrabiya screens installed in Bolzano Italy, testing two types of local hardwoods (oak and chestnut) and two softwoods (spruce, and larch) to determine their water release rate. The study recommended spruce for mashrabiya screens due to its greater cooling potential and a higher permeability and, consequently, a better evaporative cooling effect. The study concluded that larch wood could be the most appropriate species for mashrabiya screens in Bolzano given its cooling efficiency and construction features.

In the Gibson Desert of Australia, Samuels [43] proposed a new concept for a mashrabiya, which is constructed as a spray device that sprays $0.2 \mathrm{~mm}$ diameter water droplets from the connecting holes. The study indicated that the system established an effective and sufficient cooling technique for the structure, but no results or measurements of thermal efficiency and performance were given.

Karamata, et al. [44] proposed a new system inspired by the mashrabiya concept comprising a shape variable mashrabiya (SVM) and specified Abu Dhabi as a case study. The SVM was made from three identical perforated opaque shields; the first is fixed while the second and the third one can singly move along the vertical and lateral axis. The results of annual daylight performance simulations showed that SVM provides adequate and well-balanced illumination (most of the time across the whole space). In contrast, the SVM shields decrease and scatter the amount of diffuse light.

In 2015, the SVM was studied again by Karamata [45] who showed that the SVM minimised overheating problems and consequently the values of the primary energy demand for cooling $-17.2 \%$ and $-9.9 \%$ compared to selective glazing $=41 \%$ and Venetian blinds, respectively). It also minimised the primary energy required for lighting ( $-65.7 \%$ and $-30.7 \%$ compared to reflective glazing $=16 \%$ and Venetian blinds, respectively) and the efficiency of lighting and global primary energy $-27 \%$ and $-16.3 \%$ compared to RG16 and V.B., consecutively).

Sabry et al. [46] designed several solar screens in an attempt to achieve visual comfort and reduce energy use in residential desert environment. The study assumed a residential living room space of $4.30 \mathrm{~m} \times 5.20 \mathrm{~m}$ in Jeddah with different screen designs. It concentrated on the influence of varying the axial rotation of the solar screen and the aspect ratio of its openings beneath the clear desert sky. The study concluded that the solar screens could provide $66-97 \%$ daylit areas in the inspected spaces reduce energy consumption to $25 \%$ in comparison with a standard glazed window. 
Khadra and Chalfoun [47] attempted to improve an integrated façade technology that interacts with and adapts to climate change in hot arid areas, specifically in Tucson (Arizona, USA). The study aimed to optimise thermal comfort for occupants in mixedmode office buildings using passive ventilation and evaporative cooling methods in order to reduce mechanical cooling energy loads. The case was a typical office space facing south by $6 \mathrm{~m} \mathrm{(w)} \times 7.6 \mathrm{~m}(\mathrm{~d}) \times 2.7 \mathrm{~m}(\mathrm{~h})$, and a 33\% window to wall ratio. The study tested three different operating systems: a mechanical cooling system, passive ventilation and an evaporative cooling system. The proposed model demonstrated that the cooling load decreased by nearly $70 \%$ throughout the year while the heating load increased slightly in the winter months.

Batool [48] estimated the impact of a range of perforation ratios (30\%, $40 \%$ and $50 \%)$ of hexagonal jali screens on energy savings and daylight performance in a modern office building located in Lahore (Pakistan). The study comprised data collection and analysis using the IES VE simulation software for the field measurements and energy modelling. The results indicated the positive impact of jali screens on cooling loads and improved visual convenience. The $50 \%$ void ratio in windows facing south was also found to be a better way of achieving a balanced cooling and lighting energy strategy.

A new system of wooden lattice openings was proposed by Di Turi and Ruggiero [49], in order to control the daylight that enters a building. The study was carried out for an isolated test room using computational fluid dynamics (CFD) as a simulation tool, showing that this could provide better indoor conditions, increased airspeed and improved air change rate in the room. Alrashed et al. [50] integrated a mashrabiya with a simulated building in Saudi Arabia and concluded that it could reduce annual demand for electricity and maximum power need by $4 \%$ and 3\%, sequentially. Another study by Algburi and Beyhan [33] simulated an air-conditioned house in Iraq with a proposed mashrabiya and demonstrated that the use of a mashrabiya could save $12.56 \%$ of the total cooling load. Taleb and Antony [51] simulated an office building in Dubai to evaluate the performance of a mashrbiaya and different types of chosen glazing. The proposed mashrabiya had a hexagonal pattern with $40 \%$ coverage of the glazing unit. The study found that the use of mashrabiya as tinted glazing could reduce the cooling load by $23 \%$.

The integration of evaporative cooling elements with mashrabiyas has been discussed or investigated in some studies. In 2004, Schiano-Phan [52] proposed an evaporative cooling system that was derived from the mashrabiya concept using a porous ceramic medium called "Evapco system" developed by Cain, et al. [53] and the aim was to address some of the cooling needs of residential buildings in hot-dry regions. In comparison to the use of air conditioning, the total annual energy savings were about 3.08 MWh for the selected apartments.

In 2015, an innovative design inspired by a traditional mashrabiya and water-filled ceramic vessels by was reported by Rael and Fratello [54]. The form consists of 3D impressed porous ceramic bricks, where each brick absorbs water and enables air to pass. The design used the evaporative cooling principle, where the air passes through the form and evaporates the water in the pores, refracting air and reducing the internal temperature.

Table 1 summarises most of those studies in some critical criteria for this paper. As a summary of this section, most of the studies addressed either the daylight or ventilation aspects of the mashrabiya and a few included evaporative cooling. Although Samuels [43] considered all aspects, the study did not cover any analysis and measurements or simulation demonstrate the effectiveness of the proposed Mashrabiya.

Table 2 briefly highlights some of the applications from the researchers' viewpoint based on two aspects: (1) mashrabiya improvements through design and materials; (2) design of innovative mashrabiyas, which generally have an idea inspired by the design concept and functions of traditional mashrabiya. 
Table 1. Review some primary research on mashrabiyas and different aspects.

\begin{tabular}{|c|c|c|c|c|c|c|}
\hline Ref & Author, Date & Design & Daylight & Ventilation & Evaporative Cooling & Analysis \\
\hline [24] & Batterjee, 2010 & $\mathrm{~T}$ & $\checkmark$ & $x$ & $x$ & $\checkmark$ \\
\hline [25] & Maghrabi, 2000 & $\mathrm{~T}$ & $X$ & $\checkmark$ & $x$ & $\checkmark$ \\
\hline [27] & Aljofi, 2005 & $\mathrm{~T}$ & $\checkmark$ & $X$ & $x$ & $\checkmark$ \\
\hline [30] & Hariri, 1990 & S.T. & $\checkmark$ & $\checkmark$ & $x$ & $x$ \\
\hline [30] & Hariri, 1992 & $\mathrm{~T}$ & $\checkmark$ & $x$ & $x$ & $\checkmark$ \\
\hline [40] & Al-Hashimi and Semidor, 2013 & $\mathrm{~T}$ & $\checkmark$ & $x$ & $x$ & $\checkmark$ \\
\hline [43] & Samuels, 2011 & A & $\checkmark$ & $\checkmark$ & $\checkmark$ & $X$ \\
\hline [46] & Sabry et al., 2014 & ST & $\checkmark$ & $x$ & $x$ & $\checkmark$ \\
\hline [47] & Khadra and Chalfoun, 2014 & A & $x$ & $\checkmark$ & $\checkmark$ & $\checkmark$ \\
\hline [55] & Schiano-Phan, 2010 & ST & $x$ & $\checkmark$ & $\checkmark$ & $\checkmark$ \\
\hline [44] & Karamata et al., 2014 & $\mathrm{~A}$ & $\checkmark$ & $X$ & $x$ & $\checkmark$ \\
\hline [56] & Nermine and Nancy, 2014 & S.T. & $\checkmark$ & $\checkmark$ & $x$ & $\checkmark$ \\
\hline [57] & Faggal, 2015 & A & $\checkmark$ & $x$ & $\checkmark$ & $x$ \\
\hline [58] & Headley et al., 2015 & S.T. & $\checkmark$ & $\checkmark$ & $x$ & $\checkmark$ \\
\hline [59] & Alsharif, 2016 & A & $x$ & $\checkmark$ & $\checkmark$ & $x$ \\
\hline [60] & Elkhatieb and Sharples, 2016 & $\mathrm{~A}$ & $\checkmark$ & $x$ & $x$ & $\checkmark$ \\
\hline
\end{tabular}

[Design: T = Traditional]; [S.T. = Semi Traditional]; [A = Advance $]$.

Table 2. Different applications of Mashrabiya [42,43].

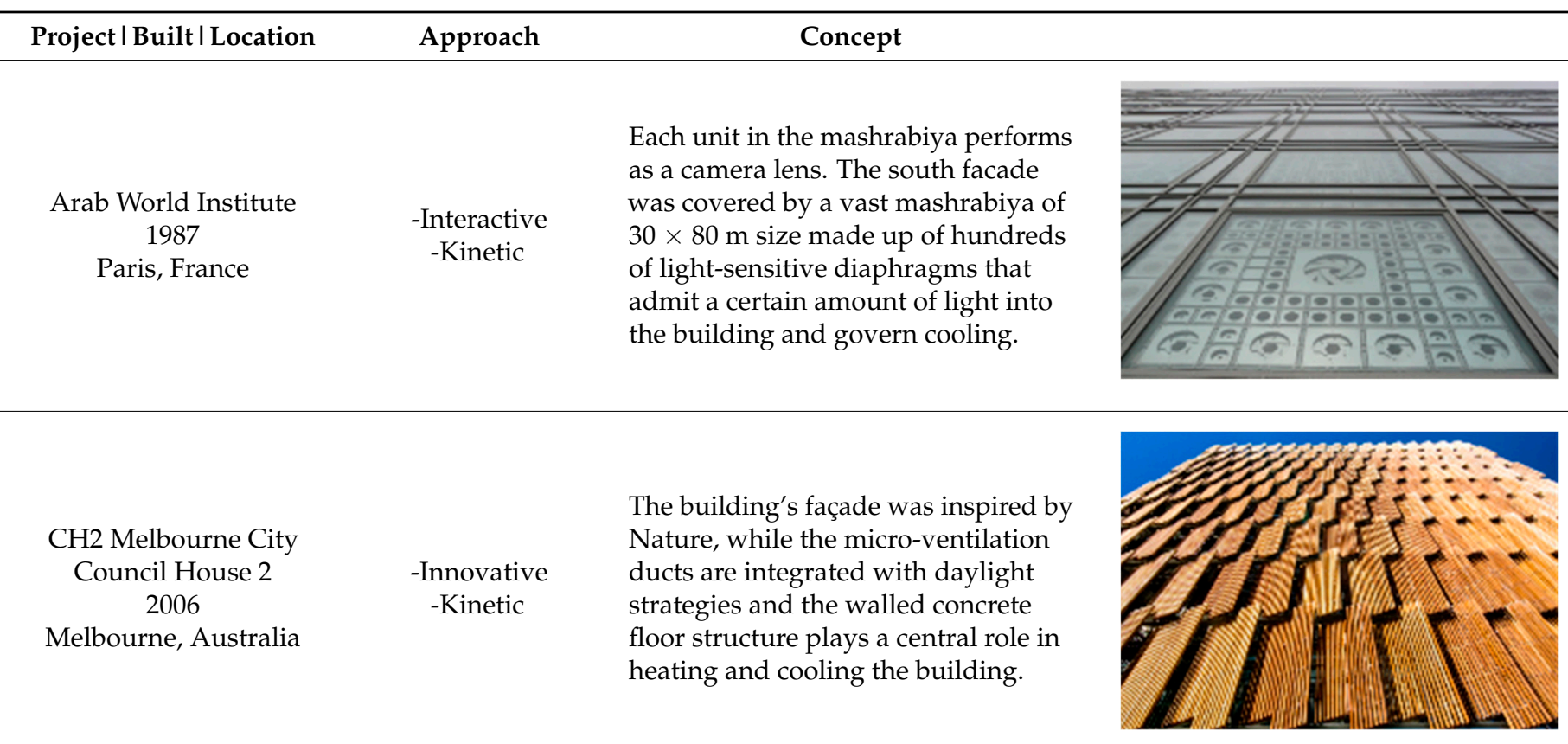


Table 2. Cont.

\begin{tabular}{cll}
\hline Project I Built I Location & Approach & \multicolumn{1}{c}{ Concept } \\
\hline & & \\
& & $\begin{array}{l}\text { The double skin is designed } 4 \mathrm{~m} \text { away } \\
\text { from the exterior walls, acts as a } \\
\text { thermal barrier that reduces direct } \\
\text { hearl Academy of Fashion } \\
\text { 2008 }\end{array}$ \\
Jaipur, India & -New Fixed Design through the windows. The \\
& -Improved & $\begin{array}{l}\text { dripping channels along the jaali } \\
\text { internal face allow passive } \\
\text { evaporative cooling, hence reducing } \\
\text { the airflow temperature. }\end{array}$ \\
& &
\end{tabular}

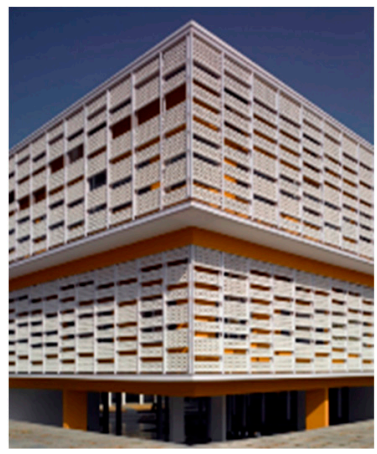

The wooden louvres on the facade act to let daylight pass and interact with

Paul Valery High School 2009

Menton, France

-New Fixed Design -Improved the exterior spaces. The design took into consideration visual unity while ensuring thermal comfort bound to solar protection.

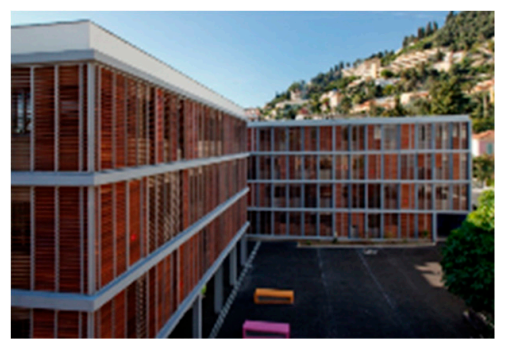

\section{Masdar city Residential Buildings 2010}

Abu Dhabi, UAE
-New Fixed Design -Improved
The mashrabiya was built to be aesthetic and integrated with the surrounding desert by using developed GRC coloured with local sand in a sustainable way. The concept of light and shadow apertures is based on typical Islamic architecture patterns.

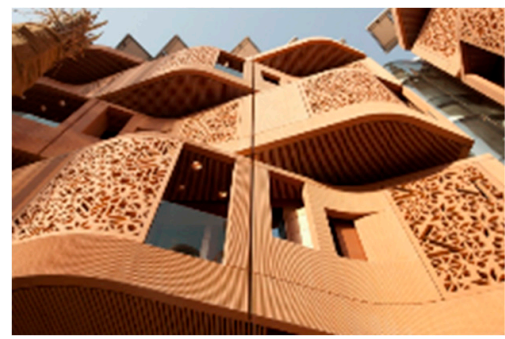

The Q1 Headquarters 2010

Essen, Germany
In response to the Sun's movment, the kinetic façade consists of about 400,000 stainless steel lamellas that allow light to be redirected without obstructing the view.

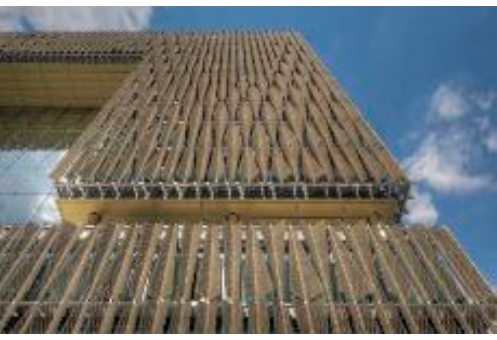

Private house 2011

New Delhi, India
-Interactive -Kinetic
-The mashrabiya is structured from -New Fixed Design -Improved moulded red brick. The brick acts as a veil in the screens that shade the west facade of the building.

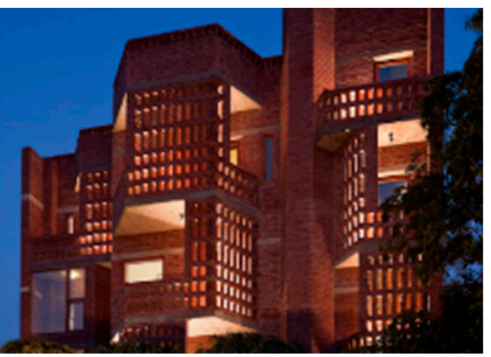


Table 2. Cont.

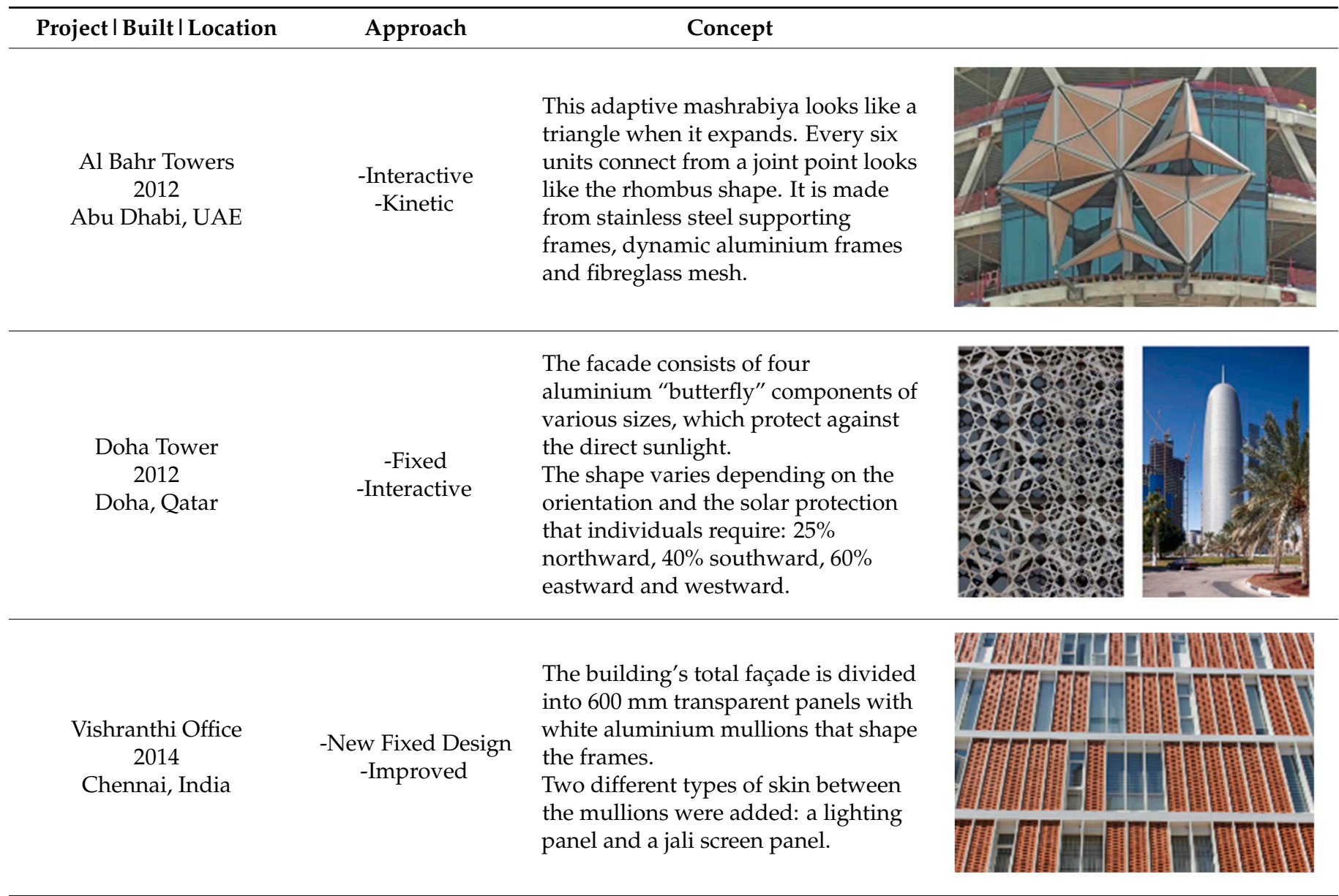

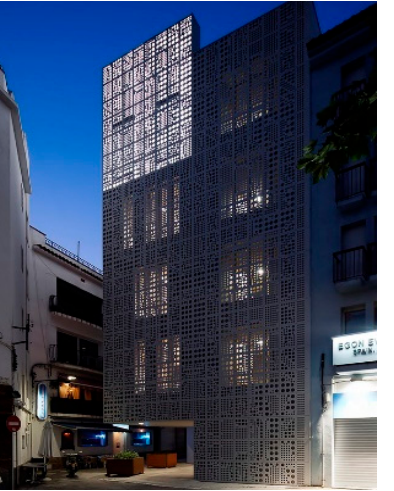

\section{The Case Study}

The building of this study is located in the heart of historic Jeddah "Al-Balad". Historic Jeddah has the most abundant area of buildings characterised by traditional mashrabiyas or roshans in Saudi Arabia. It should be pointed out that "Al-Balad" is one of the most important historical areas that the Saudi government has been keen to sponsor and support in order to preserve it as a UNESCO heritage site, as well as being one of the Vision 2030 initiatives that consider such sites as part of the heritage and civilisation of the Kingdom of Saudi Arabia.

"Baeshen House" which is the selected case study building for this work, is shown in Figure 8. The house was constructed by Mohammed Saleh Ali Abdullah Baeshen about 
200 years ago during the Ottoman era [3]. The building was built from approximately $60-80 \mathrm{~cm}$ thick load-bearing walls containing three types of stones: limestone, coral, marine and coral reef [3]. As illustrated in Figure 9, the construction walls were protected from the humidity, heat and salinity by covering them with white plaster.

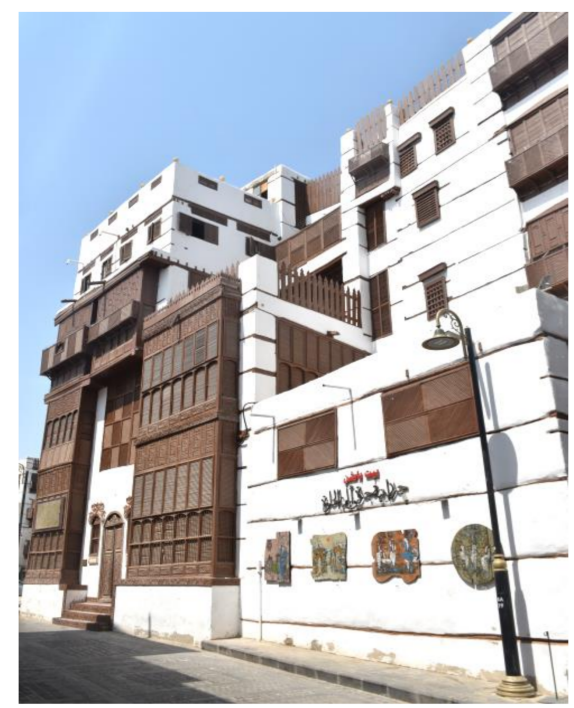

Figure 8. The building from outside.

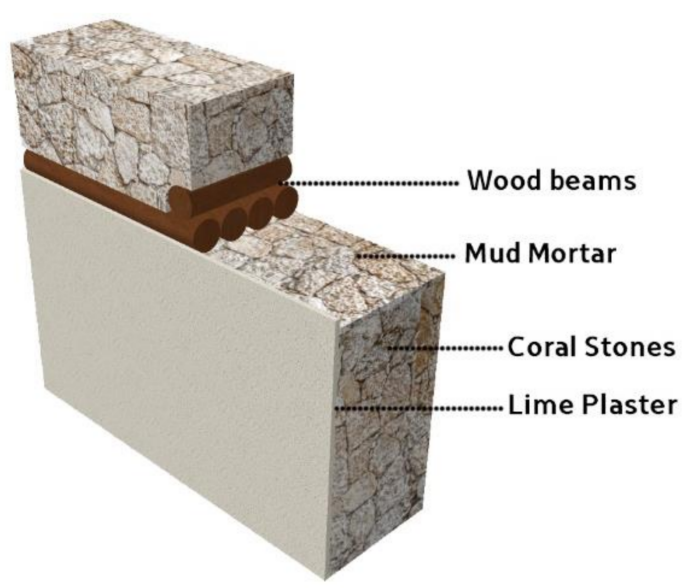

Figure 9. Cross-section view of the external wall.

The building was designed in such a way that allows effective use of natural ventilation and daylight, while the façade openings are covered with mashrabiyas of different shapes and sizes that added a distinctive aesthetic character to the building (Figure 10). Based on several criteria: validity and condition of mashrabiyas, functions and time, the availability of drawings, experimental possibilities and the access to the building, the building was selected as a case study. The results of the case study generally provide a clear framework for the mashrabiya effect and a better understanding of its actual influence on the indoor thermal comfort of old houses with load-bearing walls in Jeddah in particular and thus feed the study scope with more realistic data about the performance of the mashrabiya. 

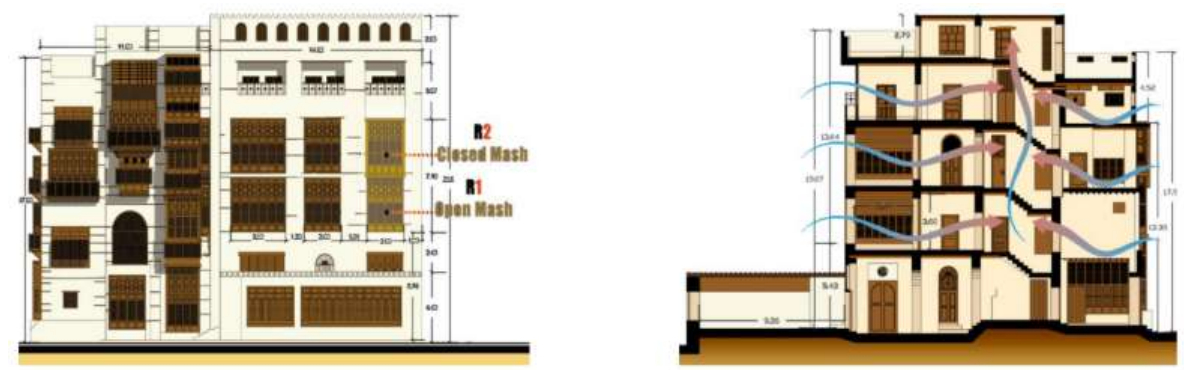

Figure 10. Western façade (left) and a cross section with a general perception of the airflow (right).

\subsection{Methods}

The fieldwork was carried out in selected historic building with mashrabiyas located in Old Jeddah in the summer of 2018 from 4 August to 1 September. The experimental investigations used calibrated digital instruments to monitor air temperature, relative humidity, air velocity, and globe temperature for two selected rooms and the courtyard (Table 3). In this study, the courtyard is an open land area adjacent to the building from the west, as shown in Figure 11.

Table 3. Overview of the building and measurement equipment.

\begin{tabular}{|c|c|c|c|}
\hline City I Location & $21^{\circ} 29^{\prime} 12.8^{\prime \prime} \mathrm{N}$ & $39^{\circ} 11^{\prime} 11.5^{\prime \prime} \mathrm{E}$ & \\
\hline Climate zone & Hot arid & & \\
\hline Building Type & Historical Residentia & Building & \\
\hline Current use & Exhibition and Gallery (Gror & nd and 1st floor) & \\
\hline \multirow{5}{*}{ Instruments (Intervals) } & Hot Wire Anemometer & $1 \mathrm{~min}$ & Indoor, Out \\
\hline & WBGT Data logger & $1 \mathrm{~min}$ & Indoor \\
\hline & Tinytag Plus 2 Dual Channel & $1 \mathrm{~h}$ & Indoor, Out \\
\hline & Tinytag View 2 & $1 \mathrm{~h}$ & Indoor, Out \\
\hline & Dual Laser Infrared Thermometer $1 \mathrm{~h}$ & $1 \mathrm{~h}$ & Indoor, Out \\
\hline Measurements & \multicolumn{3}{|c|}{$\begin{array}{c}\text { Air Temperature, Globe Temperature, Relative Humidity, Air Velocity, } \\
\text { Surface Temperature. }\end{array}$} \\
\hline Mashrabiya & \multicolumn{2}{|c|}{ Orientation: West/Mode: open-closed } & \\
\hline Materials & \multicolumn{2}{|c|}{$\begin{array}{l}\text { Wall: calcareous and coral stones } \\
\text { Celling: Stones and Timber } \\
\text { Mashrabiyas: Wood }\end{array}$} & \\
\hline
\end{tabular}

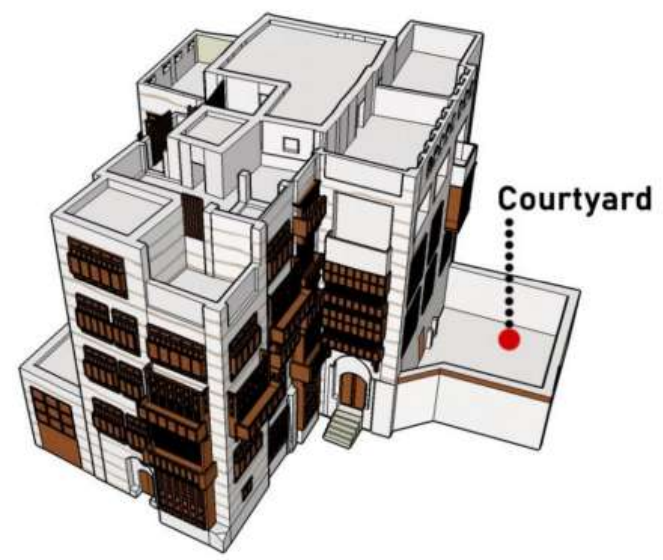

Figure 11. A 3D perspective of the building and the courtyard. 
All temperatures and relative humidity values were continuously monitored for 28 days from the first to the last day the experiment, while the other measurements; air velocity, globe temperatures, and surface temperature, were taken in specific days and periods.

The devices used for monitoring the experiment are detailed in Table 4. During the entire investigation period, each instrument was placed in a particular position. The observed rooms and courtyard during the experiment were not occupied, except for moments of setting the data loggers or carrying out some instantaneous measurements.

Table 4. The equipment used in the field work. Reproduced from Bagasi and Calautit [3].

\begin{tabular}{|c|c|c|c|}
\hline Number & Instrument & Parameters and Range & Accuracy and Resolution \\
\hline 3 & $\begin{array}{c}\text { Hot Wire Anemometer with Real-Time } \\
\text { Data Logger \#HHF2005HW }\end{array}$ & $\begin{array}{l}\text {-Air volume and velocity } \\
\text {-Range } 0.2 \text { to } 20 \mathrm{~m} / \mathrm{s}\end{array}$ & $\begin{array}{c} \pm(10 \%+1 s d) \text { Full Scale } \\
\quad \pm 0.8^{\circ} \mathrm{C}\end{array}$ \\
\hline 2 & WBGT Data Logger PCE-WB 20SD & $\begin{array}{l}\text {-Wet Bulb Globe Temperature } \\
\text {-Black globe temperature (TG) } \\
\text {-Range } 0 \text { to } 59{ }^{\circ} \mathrm{C}\end{array}$ & $\begin{array}{c}\text { WBGT: } \pm 1 \text { to } 1.5^{\circ} \mathrm{C} \\
\text { TG: } \pm 0.6^{\circ} \mathrm{C}\end{array}$ \\
\hline 2 & $\begin{array}{c}\text { Tinytag Plus } 2 \text { Dual Channel } \\
\text { Temperature/Relative Humidity } \\
\text { \#TGP-4500 }\end{array}$ & $\begin{array}{l}\text {-Temperature range }-25 \text { to }+85^{\circ} \mathrm{C} \\
\text {-Relative humidity range } 0 \text { to } 100 \% \text {. } \\
\text {-Suitable for outdoor use. }\end{array}$ & $\begin{array}{l}\text { T: } 0.01{ }^{\circ} \mathrm{C} \text { or better. } \\
\text { RH: } \pm 3.0 \% \text { at } 25^{\circ} \mathrm{C}\end{array}$ \\
\hline 1 & $\begin{array}{c}\text { Tinytag View } 2 \text { Temperature/Relative } \\
\text { Humidity Logger \#TV-4500 }\end{array}$ & $\begin{array}{l}\text {-Temperature range from }-25 \text { to }+50{ }^{\circ} \mathrm{C} \\
\text {-Relative humidity range } 0 \text { to } 100 \% \text {. } \\
\text {-Suitable for indoor use. }\end{array}$ & $\begin{array}{c}\text { T: } 0.02{ }^{\circ} \mathrm{C} \text { or better. } \\
\text { RH: Better than } 0.3 \% \text { RH }\end{array}$ \\
\hline 1 & Dual Laser Infrared Thermometer & $\begin{array}{c}\text {-Surface Temperature } \\
\text {-Rang }-50{ }^{\circ} \mathrm{C} \sim 550{ }^{\circ} \mathrm{C} \text { temperature } \\
\text {-Emissivity } 0.10 \text { to } 1.0 \text {. }\end{array}$ & $\pm 1 \%$ of reading \\
\hline
\end{tabular}

The selected rooms of this study located in the west part of the building where the first room (R1) located on the first floor and the second room (R2) in the second, as shown Figure 12. Both rooms have the same conditions, with the exception of the difference in height from ground level to each floor. Each room has one mashrabiya on the west wall and overlooks the courtyard, exposed to the prevalent wind and the Red Sea breeze. Besides, each room has three openings in each wall that were blocked to isolate and prevent the influence from adjacent rooms.
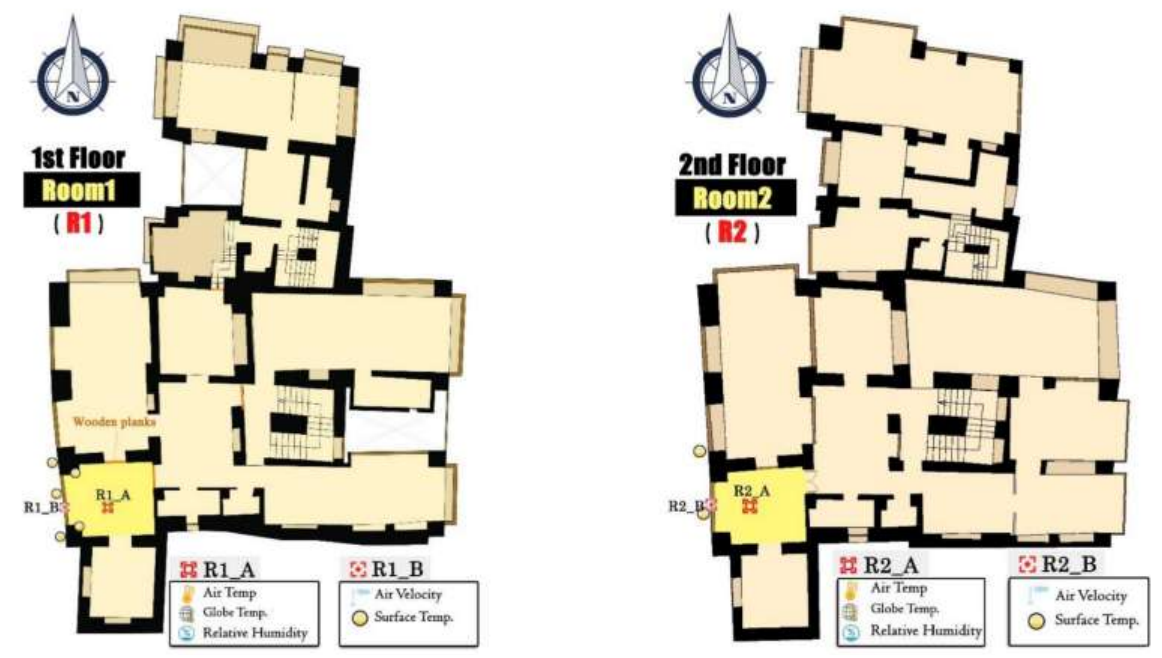

Figure 12. First and second-floor plans with the data loggers locations.

The room dimensions are $4 \mathrm{~m}$ long, $3.6 \mathrm{~m}$ wide, and $3.9 \mathrm{~m}$ high, and the mashrabiya is $2.4 \mathrm{~m}$ wide $\times 3.1 \mathrm{~m}$ high. Four data loggers were used in each room for monitoring 
the air temperature, velocity, relative humidity, and the globe temperature. In addition to that, a dual laser thermometer was used to measure the surface temperature of the mashrabiya and the adjacent walls. In order to measure the surface temperature, grid points were placed in specific spots on the mashrabiya and its adjacent walls of R1, as shown in Figure 13.
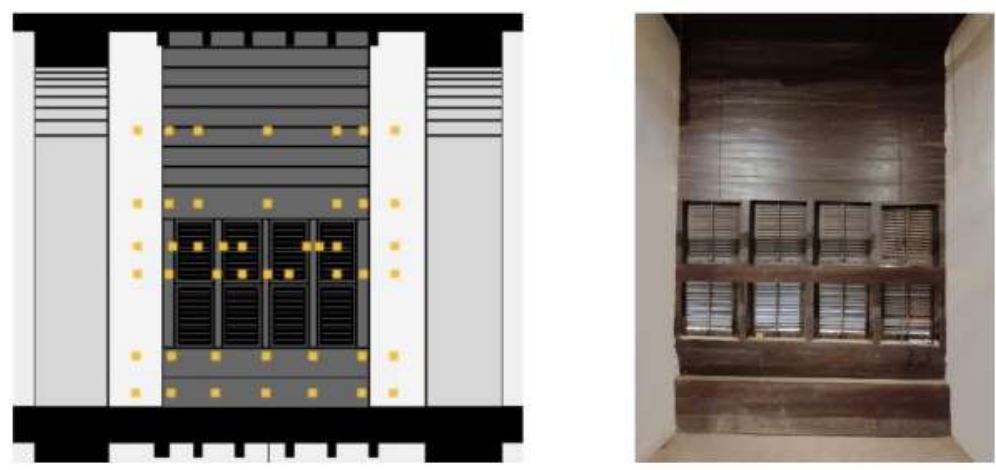

Figure 13. The mashrabiya and grids in Room 1.

The data loggers for the air and globe temperatures in both rooms were at $0.6 \mathrm{~m}$ in height and $2 \mathrm{~m}$ away from mashrabiya on the basis of ASHRAE suggestions [62]. At the internal edge of each mashrabiya at a level of about $1.1 \mathrm{~m}$, airflow velocity data loggers were placed. During the test period, each room was monitored for air and relative humidity and the global data loggers and anemometers recorded during certain times of the day.

Three meters apart from the exterior wall in the courtyard, two types of data loggers have been installed: Tinytag Plus and a anemometer. The Tinytag was recording outdoor Ta and RH from 4 August to 1 September 2018 at a level of around $1.7 \mathrm{~m}$ based on one of the levels recommended by the 2010 ASHRAE standards. The anemometer was recording specific periods of days and was placed at $0.1 \mathrm{~m}$ height and was shaded by a table. On specific days and periods of the fieldwork, a dual laser infrared thermometer was used to measure the surface temperatures of the open mash and closed mash from inside and outside including the adjacent wall of the mashrabiyas.

Figure 14 presents the timeline of the experiment indicating the days of measurements from the first day "Set up" to the last day. The chart shows that the experiments monitored the outdoor and indoor air temperature" Ta" and relative humidity " $\mathrm{RH}^{\prime}$ for the entire period. Also, the graph displays the monitoring days for the other measurements; air velocity " $\mathrm{AV}$ ", globe temperature " $\mathrm{Tg}$ ", and surface temperature " $\mathrm{Ts}$ ".

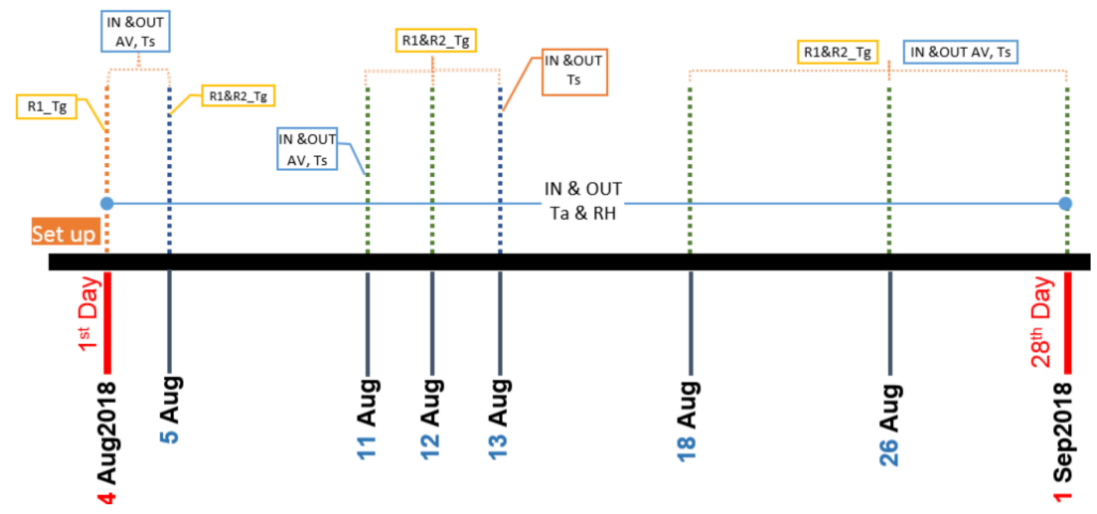

Figure 14. Timeline of the experiment. 


\subsection{Results and Discussion}

This section presents the indoor and outdoor measurements data collected in this work. The results of the air temperature, air velocity, humidity, and surface temperatures will be presented and analysed in detail.

\subsubsection{Indoor Air Temperature and Relative Humidity Results}

Figure 15 presents the measurements of indoor and outdoor air temperature from 5 to 31 August. As observed, the thermal mass and the mashrabiya played a an important role in regulating the indoor temperature during the high fluctuations where the temperature of Room 1 ranged between 32.2 and $38.5^{\circ} \mathrm{C}$, Room 2 from 32.5 to $38.4^{\circ} \mathrm{C}$, whilst there was a recorded high variation in the courtyard temperatures between 30.9 and $48.7^{\circ} \mathrm{C}$. The thermal mass and closed mashrabiya delayed the heat flux into Room 2 up to three hours per day while the open mashrabiya in Room 1 reduced the time lag to one hour as shown in Figure 16. However, the open mashrabiya allowed more airflow, which mostly lowered the Room 1 temperature, especially during the afternoon by up to $2.4^{\circ} \mathrm{C}$ compared to Room 2 . As observed in Figure 16, both rooms were able to keep the temperature below $38^{\circ} \mathrm{C}$ when the outdoor temperature peaked at $43.6-45.4^{\circ} \mathrm{C}$. This effect is again mainly attributed to the role of the building's total thermal mass. It can also be observed that night ventilation effect decreased the indoor air temperature up to $34^{\circ} \mathrm{C}$ and contributed to lowering the excess heat and cool the building fabric. Also, it helped to reduce and delay the peak time of the indoor temperatures.

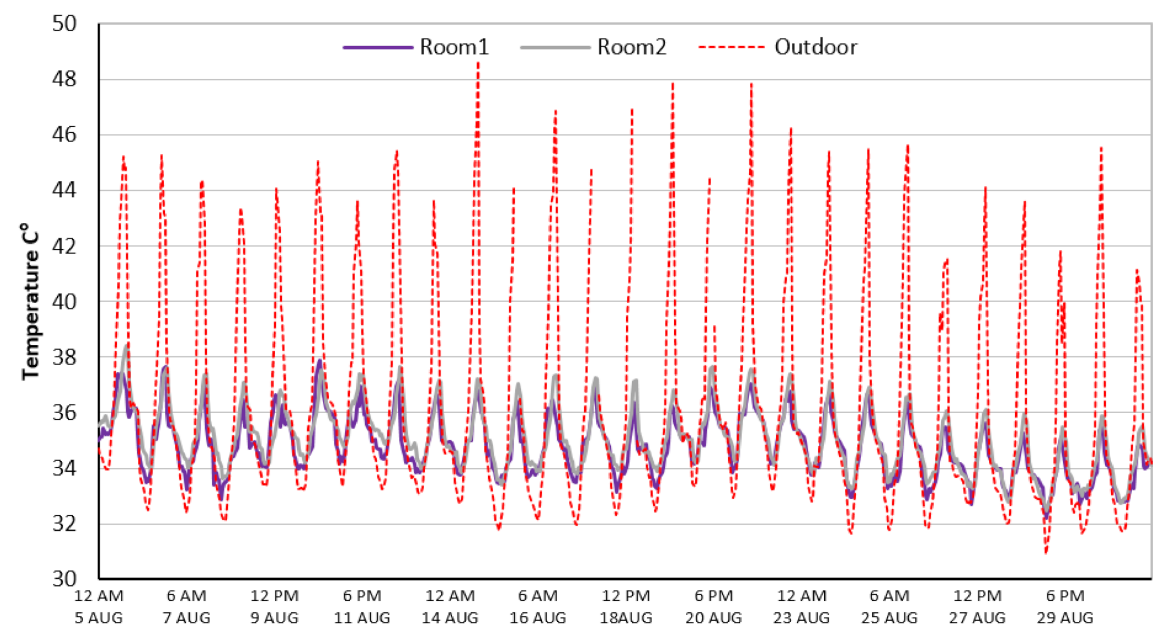

Figure 15. Indoor and outdoor air temperature from 5 to 31 August 2018.

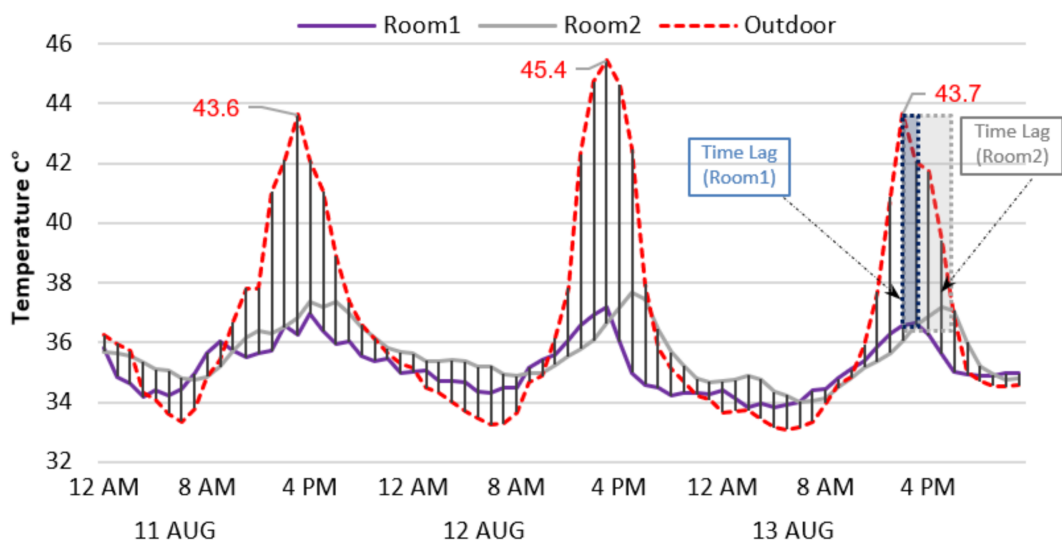

Figure 16. Hourly indoor and outdoor air temperature on 11, 12 \& 13 August 2018. 
The average air temperature and relative humidity results from the fieldwork measurements for the outdoor and selected rooms are shown in Table 5. The measurements were carried out from 4 August until 1 September 2018 for each space. All air temperature and relative humidity data were recorded for $24 \mathrm{~h}$ in all dates except the first and last day due to the data loggers' setup. As shown in Table, 5 August recorded the highest average air temperature in both rooms when the outdoor recorded the hottest by $37.62{ }^{\circ} \mathrm{C}$. In contrast, the lowest indoor air temperature averages were recorded on 29 August when the average outdoor air temperature reaches the lowest by $37.62{ }^{\circ} \mathrm{C}$. As occurred to the indoor air temperature from the influence of the outdoor air temperature, the rooms were clearly affected by the outdoor relative humidity. The highest relative humidity in all spaces was on 31 August and the lowest on 23 August with variation rates less than 3\%.

Table 5. Daily average air temperature (Ta) and relative humidity (RH) for the selected spaces.

\begin{tabular}{|c|c|c|c|c|c|c|}
\hline \multirow{2}{*}{ Date } & \multicolumn{2}{|c|}{ Room1 } & \multicolumn{2}{|c|}{ Room 2} & \multicolumn{2}{|c|}{ Outdoor } \\
\hline & $\mathrm{Ta}$ & RH & $\mathrm{Ta}$ & RH & Ta & RH \\
\hline $4 \mathrm{AUG}$ & 36.76 & 39.91 & 36.72 & 38.07 & 41.68 & 33.59 \\
\hline $5 \mathrm{AUG}$ & 36.11 & 48.21 & 36.41 & 46.88 & 37.62 & 47.12 \\
\hline $6 \mathrm{AUG}$ & 35.18 & 55.01 & 35.58 & 53.05 & 36.51 & 53.73 \\
\hline $7 \mathrm{AUG}$ & 34.71 & 61.68 & 35.31 & 56.66 & 36.13 & 58.12 \\
\hline $8 \mathrm{AUG}$ & 34.56 & 63.42 & 35.01 & 60.78 & 36.05 & 60.84 \\
\hline 9 AUG & 35.23 & 48.96 & 35.31 & 47.82 & 36.60 & 47.40 \\
\hline $10 \mathrm{AUG}$ & 35.53 & 47.72 & 35.60 & 48.59 & 37.05 & 48.73 \\
\hline 11 AUG & 35.47 & 53.58 & 35.96 & 49.36 & 37.06 & 49.48 \\
\hline 12 AUG & 35.08 & 58.99 & 35.65 & 55.28 & 36.68 & 56.83 \\
\hline 13 AUG & 34.96 & 56.63 & 35.19 & 55.98 & 35.93 & 56.79 \\
\hline 14 AUG & 35.04 & 51.91 & 35.18 & 49.75 & 36.88 & 48.80 \\
\hline 15 AUG & 34.43 & 53.02 & 34.81 & 50.21 & 34.82 & 53.49 \\
\hline 16 AUG & 34.90 & 52.71 & 35.15 & 50.44 & 36.48 & 49.79 \\
\hline $17 \mathrm{AUG}$ & 34.95 & 48.90 & 35.10 & 48.42 & 35.55 & 50.68 \\
\hline 18 AUG & 34.50 & 57.04 & 35.02 & 53.94 & 35.51 & 54.90 \\
\hline 19 AUG & 34.64 & 59.51 & 35.03 & 56.43 & 36.50 & 55.63 \\
\hline 20 AUG & 35.35 & 49.92 & 35.61 & 49.92 & 36.37 & 48.91 \\
\hline $21 \mathrm{AUG}$ & 35.61 & 48.96 & 35.78 & 47.60 & 37.46 & 46.07 \\
\hline $22 \mathrm{AUG}$ & 35.38 & 46.19 & 35.58 & 45.18 & 36.66 & 46.06 \\
\hline 23 AUG & 35.01 & 43.53 & 35.07 & 42.87 & 36.26 & 43.02 \\
\hline 24 AUG & 34.76 & 45.34 & 34.87 & 44.01 & 35.84 & 44.85 \\
\hline 25 AUG & 34.55 & 54.93 & 34.84 & 52.70 & 35.93 & 53.13 \\
\hline 26 AUG & 34.11 & 62.43 & 34.53 & 59.14 & 35.06 & 61.65 \\
\hline $27 \mathrm{AUG}$ & 34.20 & 55.75 & 34.34 & 54.40 & 35.44 & 54.77 \\
\hline 28 AUG & 33.92 & 53.80 & 34.09 & 52.42 & 35.06 & 53.23 \\
\hline 29 AUG & 33.54 & 56.04 & 33.68 & 53.63 & 34.41 & 55.17 \\
\hline 30 AUG & 33.77 & 63.50 & 34.04 & 60.91 & 35.19 & 61.36 \\
\hline 31 AUG & 33.66 & 67.42 & 33.91 & 64.97 & 34.71 & 65.95 \\
\hline 1 SEP & 34.29 & 63.17 & 34.33 & 61.54 & 35.84 & 60.07 \\
\hline
\end{tabular}

Bule: Maximum Average Relative Humidity; Pink: Maximum Average Air Temperature; Orange:

Minimum Average Relative Humidity; Green: Minimum Average Air Temperature.

Figure 17a shows the relationship between average air temperature (Ta) and relative humidity (RH) in Room 1, Room 2 and the courtyard between 5 and 31 August 2018. As expected, the relative humidity decreases as the air temperature in both rooms increases and vice versa. The highest relative humidity was recorded on 31 August with a range of about 65 and $67.4 \%$ while the lowest was $43 \%$ on 23 August. Due to airflow into the Room 1 through the open mashrabiya, Room 1 reduced more heat and allowed more relative humidity than Room 2. 


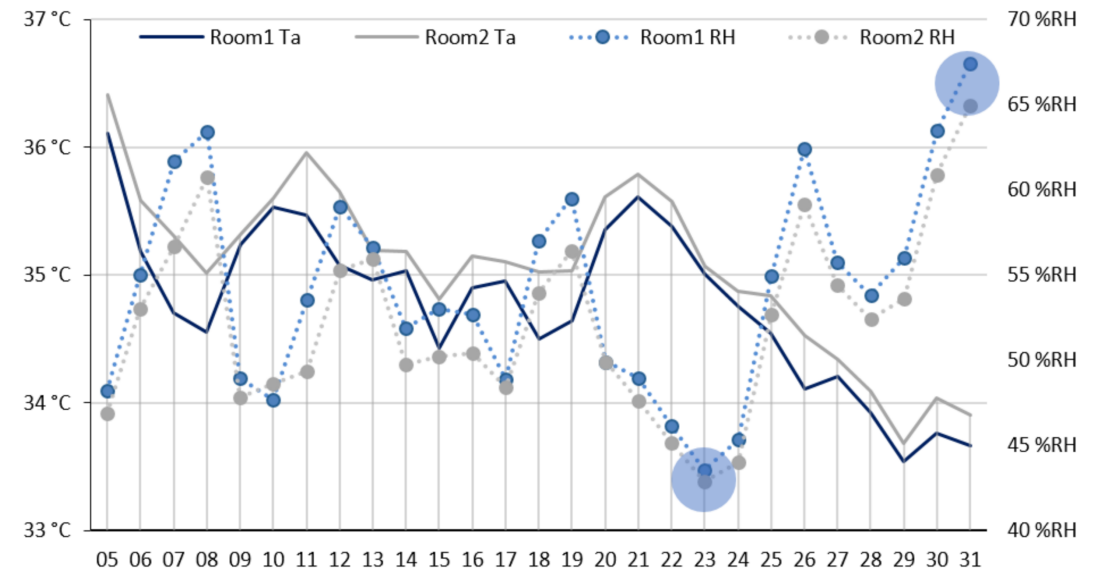

(a)

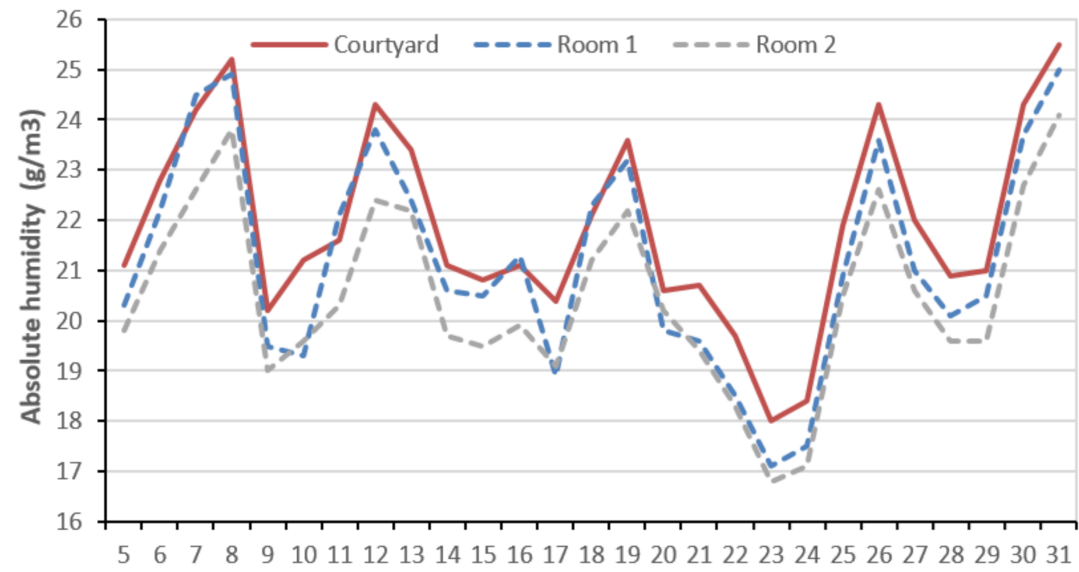

(b)

Figure 17. (a). Average air temperature and relative humidity for R1 and R2 from 5 to 31 August 2018; (b). The daily Absolute humidity for each room and courtyard from 5 to 31 August 2018.

The average daily indoor and outdoor absolute humidity from 5 to 31 August 2018 are presented in Figure 17b. The graph demonstrates that the absolute humidity rates in the rooms were affected by the outdoor absolute humidity. The rooms' averages of absolute humidity ranged between 16.8 and $25 \mathrm{~g}$ of moisture per cubic meter of air $\left(\mathrm{g} / \mathrm{m}^{3}\right)$ and in the courtyard from 18 to $25.5 \mathrm{~g} / \mathrm{m}^{3}$.

\subsubsection{Indoor Air Velocity Results}

Table 6 demonstrates the frequency percentages and maximum indoor and outdoor air velocity during a specific period of days. The monitoring days included $4-5,11-12$, 18, 26 August and 1 September during the afternoon hours. It should be pointed out that the rooms airflow velocities were measured at a specific point at each mashrabiya, as mentioned earlier in the method part. Moreover, the mashrabiya for Room 2 was not completely closed due to the difficulty of moving the tilting rods, which caused the amount of natural daylight to pass and the airflow through the openings of the semi-open mashrabiya slats. As for the courtyard air velocity, readings maybe were influenced by several factors such as the anemometers position, proximity to ground level, and some surrounding obstacles. 
Table 6. Frequency of indoor and outdoor air velocity measurements.

\begin{tabular}{|c|c|c|c|c|c|c|c|c|c|c|c|}
\hline \multicolumn{4}{|c|}{ Courtyard } & \multicolumn{4}{|c|}{ Room1 } & \multicolumn{4}{|c|}{ Room2 } \\
\hline & Bin & Freq $\%$ & & & Bin & Freq $\%$ & & & Bin & Freq $\%$ & \\
\hline & 0 & 24.65 & & & 0 & 1.32 & & & 0 & 90.44 & \\
\hline & 0.5 & 28.90 & & & 0.5 & 7.64 & & & 0.1 & 1.97 & \\
\hline & 1 & 25.76 & & & 1 & 15.69 & & & 0.2 & 2.02 & \\
\hline & 1.5 & 12.15 & & & 1.5 & 17.56 & & & 0.3 & 1.92 & \\
\hline & 2 & 4.35 & & & 2 & 18.27 & & & 0.4 & 1.27 & \\
\hline & 2.5 & 1.77 & & & 2.5 & 14.37 & & & 0.5 & 0.81 & \\
\hline & 3 & 0.66 & & & 3 & 9.41 & & & 0.6 & 0.76 & \\
\hline & 3.5 & 0.46 & & & 3.5 & 6.98 & & & 0.7 & 0.30 & \\
\hline & 4 & 0.40 & & & 4 & 4.71 & & & 0.8 & 0.25 & \\
\hline & 4.5 & 0.20 & & & 4.5 & 2.28 & & & 0.9 & 0.15 & \\
\hline & 5 & 0.05 & & & 5 & 0.96 & & & 1 & 0.05 & \\
\hline & 5.5 & 0.20 & & & 5.5 & 0.35 & & Max & 1.1 & 0.05 & $\begin{array}{c}\text { 04-Aug-18 } \\
\text { 2:53pm }\end{array}$ \\
\hline & 6 & 0.10 & & & 6 & 0.30 & & & & & \\
\hline & 6.5 & 0.10 & & & 6.5 & 0.10 & & & & & \\
\hline & 7 & 0.05 & & Max & 6.9 & 0.05 & $\begin{array}{c}\text { 11-Aug-18 } \\
1: 07 \mathrm{pm}\end{array}$ & & & & \\
\hline & 7.5 & 0.05 & & & & & & & & & \\
\hline & 8 & 0.10 & & & & & & & & & \\
\hline Max & 8.1 & 0.05 & $\begin{array}{c}\text { 12-Aug-18 } \\
\text { 3:12am }\end{array}$ & & & & & & & & \\
\hline
\end{tabular}

The table displays the ranges of indoor and outdoor air velocity that are varying from 0 to $8.1 \mathrm{~m} / \mathrm{s}$ in courtyard, 0 to $6.9 \mathrm{~m} / \mathrm{s}$ in Room 1, and 0 to $1.1 \mathrm{~m} / \mathrm{s}$ in Room 2 . According to the table, the highest frequency value of air velocity was in Room 1 with speed $2 \mathrm{~m} / \mathrm{s}$ $(18.27 \%)$, courtyard $0.5 \mathrm{~m} / \mathrm{s}(28.9 \%)$ and in Room 2 by $0 \mathrm{~m} / \mathrm{s}(90.44 \%)$. In general, the air velocity rates through the mashrabiya of Room 1 was greater than courtyard and Room 2 due to the opening the mashrabiya, which admitted more airflow without being affected by obstacles as in the courtyard or when been closed as the mashrabiya of Room 2 .

\subsubsection{Statistical Analysis of Indoor and Outdoor Measurements}

Table 7 presents a brief of statistical comparisons between the air velocity (Av) and air temperature (Ta) for; the open mashrabiya in R1, the closed mashrabiya in R2, and courtyard. Dates included in this table were only restricted to days that covered the same period for monitoring both air temperature and velocity. The measurement times of each day covered the period from noon to 3:30 p.m. The maximum air velocity values of the R1 range from 4.50 to $6.90 \mathrm{~m} / \mathrm{s}$, courtyard from 1.60 to $5.20 \mathrm{~m} / \mathrm{s}$, and R2 from 0 to $1.10 \mathrm{~m} / \mathrm{s}$. This indicates that the room with open mashrabiya has higher air velocity than the courtyard which is the benchmark and the room with closed mashrabiya. The lowest standard deviation values were calculated in R2 and the highest in R1, which mean that there is inconsistency in R1 in air velocity compared to R2 and the courtyard. This may be due to the low air velocity in $\mathrm{R} 2$ and the courtyard, which equivalent to zero some periods. 
Table 7. Statistical comparisons between indoor and outdoor air velocity and temperature.

\begin{tabular}{|c|c|c|c|c|c|c|c|c|c|}
\hline \multirow{2}{*}{ Space } & \multirow{2}{*}{ Date } & \multicolumn{4}{|c|}{ Air Velocity (m/s) } & \multicolumn{4}{|c|}{ Air Temperature $\left({ }^{\circ} \mathrm{C}\right)$} \\
\hline & & MAX & AVG & MIN & S.D. & MAX & AVG & MIN & S.D. \\
\hline \multirow{6}{*}{ Room1 } & 04-Aug-18 & 5.20 & 2.37 & 0.30 & 0.97 & 39.3 & 37.0 & 35 & 1.0 \\
\hline & 05-Aug-18 & 4.50 & 2.03 & 0.00 & 0.89 & 38.1 & 37.0 & 35.8 & 0.5 \\
\hline & 11-Aug-18 & 6.90 & 1.71 & 0.00 & 1.14 & 38.4 & 35.4 & 33.1 & 0.8 \\
\hline & 18-Aug-18 & 6.40 & 2.63 & 0.10 & 1.13 & 36.6 & 34.1 & 32.7 & 0.7 \\
\hline & 26-Aug-18 & 5.30 & 2.08 & 0.20 & 0.76 & 36.1 & 34.6 & 33.1 & 0.6 \\
\hline & 01-Sep-18 & 4.80 & 2.17 & 0.00 & 1.03 & 36.7 & 34.8 & 33.1 & 0.8 \\
\hline \multirow{6}{*}{ Room2 } & 04-Aug-18 & 1.10 & 0.27 & 0.00 & 0.26 & 41.8 & 39.3 & 36.9 & 1.6 \\
\hline & 05-Aug-18 & 0.10 & 0.00 & 0.00 & 0.01 & 43.4 & 40.9 & 38.4 & 1.1 \\
\hline & 11-Aug-18 & 0.00 & 0.00 & 0.00 & 0.00 & 41.6 & 38.1 & 35.8 & 1.7 \\
\hline & 18-Aug-18 & 0.20 & 0.01 & 0.00 & 0.03 & 40.2 & 37.0 & 34.6 & 1.5 \\
\hline & 26-Aug-18 & 0.00 & 0.00 & 0.00 & 0.00 & 40 & 37.5 & 35.0 & 1.3 \\
\hline & 01-Sep-18 & 0.70 & 0.06 & 0.00 & 0.12 & 40 & 37.8 & 36.3 & 1.0 \\
\hline \multirow{6}{*}{ Courtyard } & 04-Aug-18 & 2.80 & 0.78 & 0.00 & 0.63 & 48.3 & 41.8 & 36.8 & 2.2 \\
\hline & 05-Aug-18 & 3.20 & 0.71 & 0.00 & 0.58 & 46 & 40.7 & 37.7 & 1.4 \\
\hline & 11-Aug-18 & 3.70 & 0.45 & 0.00 & 0.50 & 43.2 & 37.0 & 34.3 & 1.6 \\
\hline & 18-Aug-18 & 3.40 & 0.80 & 0.00 & 0.63 & 46.4 & 38.9 & 34.9 & 2.4 \\
\hline & 26-Aug-18 & 1.60 & 0.51 & 0.00 & 0.38 & 46.1 & 39.6 & 35.9 & 1.8 \\
\hline & 01-Sep-18 & 5.20 & 1.02 & 0.00 & 1.06 & 45 & 38.4 & 33.4 & 2.5 \\
\hline
\end{tabular}

The maximum Room 1 air temperature ranges from 36.1 to $39.3^{\circ} \mathrm{C}, \mathrm{R} 2$ from 40 to $43.4^{\circ} \mathrm{C}$, and the courtyard from 43.2 to $48.3^{\circ} \mathrm{C}$. The average air temperature measurements of the R1 range from 33.8 to $37^{\circ} \mathrm{C}$, R2 from 37 to $40.9{ }^{\circ} \mathrm{C}$, and courtyard from 37 to $41.8^{\circ} \mathrm{C}$. The lowest value of minimum air temperature was monitored in $\mathrm{R} 132.7^{\circ} \mathrm{C}$. From this; it can elicit that the higher air velocity can improve the air temperature. For example, the lowest standard deviation values have been calculated in R1 and the highest in the courtyard. The lowest standard deviation values have been calculated in R1 and the highest in the courtyard. This means R1 have more consistency in air temperature and lowest in the fluctuations. However, the room with open mashrabiya shows better air velocity and air temperature than the courtyard and Room 2.

Table 8 presents the air temperature (Ta) and air velocity (Av) correlation coefficient for Room 1 and the courtyard of specific dates during the same period, from 12 p.m. to 3:30 p.m. It can be noticed from the table that the relationships between the variables $\mathrm{Av}$ and $\mathrm{Ta}$ in both spaces are negative correlation. In Room 1, the correlation coefficient ranges from -0.19 to -0.54 , which can be evaluated as weak to moderate correlation. In comparison, the correlation coefficient in the courtyard ranges from -0.10 to -0.68 , which can be evaluated as weak to strong correlation. It may be concluded from this table that as air velocity increases, the indoor air temperature may decrease.

Table 8. The air temperature and velocity correlation coefficient for Room 1 and the courtyard.

\begin{tabular}{ccccccc}
\hline & 4 Aug & 5 Aug & 11 Aug & 18 Aug & 26 Aug & 1 Sep \\
\hline Room 1 & -0.19 & -0.45 & -0.5 & -0.05 & -0.19 & -0.54 \\
\hline Courtyard & -0.59 & -0.68 & -0.62 & -0.69 & -0.1 & -0.67 \\
\hline
\end{tabular}

Table 9 provides a statistical summary of indoor and outdoor averages and ranges of air temperature, relative humidity, air velocity, and the indoor globe temperatures. The range (RNG) values in the table refer to the difference between the maximum and minimum readings of each space for a day. The table only displays the days when all thermal measurements were taken for all observed spaces. It should be noted that globe temperature (Tg) readings in $\mathrm{R} 2$ on $4 \& 5$ August were not listed due to an issue in the inserted SD card memory. 
Table 9. Summary of thermal conditions during different days of the experiment.

\begin{tabular}{|c|c|c|c|c|c|c|c|c|c|c|c|c|}
\hline \multirow{2}{*}{ Date } & \multirow{2}{*}{ DESC } & \multicolumn{3}{|c|}{$\mathrm{T}\left({ }^{\circ} \mathrm{C}\right)$} & \multicolumn{2}{|c|}{ Globe Temperature $\left({ }^{\circ} \mathrm{C}\right)$} & \multicolumn{3}{|c|}{ RH (\%) } & \multicolumn{3}{|c|}{$\operatorname{Av}(\mathrm{m} / \mathrm{s})$} \\
\hline & & R1 & $\mathbf{R} 2$ & Out & R1 & $\mathbf{R} 2$ & R1 & $\mathbf{R} 2$ & Out & R1 & $\mathbf{R 2}$ & Out \\
\hline \multirow{2}{*}{4 AUG } & AVG & 36.8 & 36.7 & 41.7 & 37.0 & $\mathrm{n} / \mathrm{a}$ & 39.9 & 38.1 & 33.6 & 2.4 & 0.3 & 0.8 \\
\hline & RNG & 3.8 & 3.9 & 19.6 & 3.9 & $\mathrm{n} / \mathrm{a}$ & 27.7 & 13.8 & 29.1 & 4.9 & 1.1 & 2.8 \\
\hline \multirow{2}{*}{5 AUG } & AVG & 36.1 & 36.4 & 37.6 & 36.8 & $\mathrm{n} / \mathrm{a}$ & 48.2 & 46.9 & 47.1 & 2.0 & 0 & 0.7 \\
\hline & RNG & 2.3 & 3 & 11.3 & 2.9 & $\mathrm{n} / \mathrm{a}$ & 23.1 & 17.5 & 29.3 & 4.5 & 0.1 & 3.2 \\
\hline \multirow{2}{*}{11 AUG } & AVG & 35.5 & 36.0 & 37.1 & 35.0 & 35.9 & 53.6 & 49.4 & 49.5 & 1.7 & 0 & 0.4 \\
\hline & RNG & 2.8 & 2.6 & 10.3 & 3.6 & 3.2 & 31.3 & 28.3 & 37 & 6.9 & 0 & 3.7 \\
\hline \multirow{2}{*}{12 AUG } & AVG & 35.1 & 35.7 & 36.7 & 34.9 & 35.7 & 59.0 & 55.3 & 56.8 & 0.8 & 0 & 0.9 \\
\hline & RNG & 2.9 & 3 & 12.2 & 3.4 & 3.2 & 23.9 & 19.6 & 45 & 2.7 & 0 & 8.1 \\
\hline \multirow{2}{*}{18 AUG } & AVG & 34.5 & 35.0 & 35.5 & 34.4 & 35.5 & 57.0 & 53.9 & 54.9 & 2.6 & 0 & 0.8 \\
\hline & RNG & 3.2 & 3.3 & 14.6 & 7.3 & 2.2 & 34.7 & 30.9 & 37.4 & 6.3 & 0.2 & 3.4 \\
\hline \multirow{2}{*}{26 AUG } & AVG & 34.1 & 34.5 & 35.1 & 34.7 & 35.3 & 62.4 & 59.1 & 61.7 & 2.1 & 0 & 0.5 \\
\hline & RNG & 2.6 & 2.6 & 9.7 & 1.7 & 1.6 & 28.3 & 28.8 & 35.1 & 5.1 & 0 & 1.6 \\
\hline \multirow{2}{*}{$1 \mathrm{SEP}$} & AVG & 34.3 & 34.3 & 35.8 & 35.0 & 35.4 & 63.2 & 61.5 & 60.1 & 2.2 & 0.1 & 1.0 \\
\hline & RNG & 3.4 & 2.8 & 9.4 & 1.2 & 1.6 & 16.2 & 9.4 & 25.5 & 4.8 & 0.7 & 5.2 \\
\hline
\end{tabular}

The highest average of the outdoor temperature was recorded $41.7^{\circ} \mathrm{C}$ on 4 August with a range of 19.6 degrees as can be observed from the table. It is worth noting that some of the readings may have been affected somewhat because the data logger was not shaded properly during some periods of the day. However, the outdoor temperature range for 4 August was reflected on the indoor values as both rooms recorded the highest average and range on the same day. On the averages of indoor air temperature, Room 1 was lower by 0.5 than Room 2 .

The average globe temperature values $(\mathrm{Tg})$ for both rooms were close to the average air temperature, indicating the absence or low thermal radiation. Furthermore, the variations between indoor air temperature and globe temperature measurements have not exceeded two degrees.

The highest range of relative humidity was $45 \%$ in the courtyard on 12 August, while the highest average relative humidity was recorded on the last day of the experiment by $63.2 \%$ in Room 1, 61.5\% in Room 2, and $60.1 \%$ in the courtyard. Despite the higher relative humidity ranges in the courtyard, the rooms on averages were wetter than the courtyard, which is beneficial for thermal comfort. This behaviour was attributed to the building envelope that reduced temperature fluctuations, thus leading to more moisture stability inside the building.

The highest averages and ranges for air velocity were mostly recorded in Room 1 due to the open mashrabiya facing air directly without being affected by obstacles or closure.

Surface temperature values were measured for the open mashrabiya and closed mashrabiya from inside and outside, and the courtyard, as shown in the next tables. All averages of measuring points at various positions, days and times are displayed in Tables 10-12. The points represent the averages of measurement areas for the open mashrabiya (Mash1), closed mashrabiya (Mash2) and walls beside each mashrabiya from inside and outside (Figures 18 and 19). 
Table 10. Surface temperature measurements of Room 1, Room 2, and the courtyard on 4 and 5 August 2018.

\begin{tabular}{|c|c|c|c|c|c|c|c|c|}
\hline \multirow[b]{2}{*}{ Time } & \multicolumn{3}{|c|}{4 August } & \multicolumn{4}{|c|}{5 August } & \\
\hline & 1:00 p.m. & 2:00 p.m. & 3:00 p.m. & 12:00 p.m. & 1:00 p.m. & 2:00 p.m. & 3:00 p.m. & \\
\hline A M1 & 38.0 & 38.9 & 39.8 & 38.2 & 38.2 & 38.1 & 38.6 & \multirow{16}{*}{ 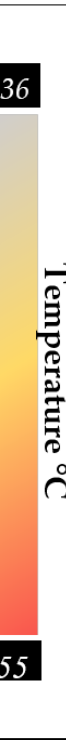 } \\
\hline B M1 & 38.1 & 39.2 & 40.2 & 39.2 & 38.4 & 38.8 & 39.8 & \\
\hline C M1 & 37.3 & 37.5 & 38.8 & 37.8 & 37.7 & 38.0 & 38.4 & \\
\hline WA M1 & 36.9 & 36.7 & 38.3 & 38.4 & 37.7 & 37.3 & 37.9 & \\
\hline WB M1 & 36.7 & 36.7 & 38.1 & 38.3 & 37.8 & 37.2 & 37.7 & \\
\hline A M2 & 39.0 & 39.4 & 41.0 & 42.0 & 41.0 & 40.6 & 41.5 & \\
\hline B M2 & 40.0 & 41.5 & 44.0 & 43.0 & 41.5 & 42.0 & 43.8 & \\
\hline C M2 & 37.0 & 39.0 & 45.8 & 42.0 & 40.5 & 40.2 & 41.2 & \\
\hline WR M2 & & & & & & & & \\
\hline WL M2 & & & & & & & & \\
\hline OWR M1 & & & & & & & & \\
\hline \multicolumn{8}{|l|}{ OWL M1 } & \\
\hline $\mathrm{AO}$ & 47.0 & 49.0 & 51.0 & 49.0 & 47.0 & 49.5 & 53.0 & \\
\hline $\mathrm{BO}$ & 49.0 & 50.0 & 55.0 & 47.0 & 49.0 & 47.0 & 50.0 & \\
\hline $\mathrm{CO}$ & 43.0 & 43.0 & 45.0 & 46.0 & 47.0 & 49.0 & 49.0 & \\
\hline $\mathrm{WO}$ & & & 43.0 & 42.0 & 44.0 & 44.0 & 45.0 & \\
\hline
\end{tabular}

Table 11. Surface temperatures of Room 1, Room 2, and the courtyard on 11, 13 and 18 August 2018.

\begin{tabular}{|c|c|c|c|c|c|c|c|c|c|c|}
\hline \multirow[b]{2}{*}{ Time } & \multicolumn{4}{|c|}{11 August } & \multirow{2}{*}{$\begin{array}{c}\begin{array}{c}13 \mathrm{Au}- \\
\text { gust }\end{array} \\
\text { 6:00p.m. }\end{array}$} & \multicolumn{4}{|c|}{18 August } & \\
\hline & $\begin{array}{l}\text { 12:00 } \\
\text { p.m. }\end{array}$ & 1:00 p.m. & 2:00 p.m. & 3:00 p.m. & & $\begin{array}{l}\text { 12:00 } \\
\text { p.m. }\end{array}$ & 1:00 p.m. & 2:00 p.m. & 3:00 p.m. & \\
\hline A M1 & 36.5 & 36.1 & 35.4 & 35.9 & 36.9 & 35.0 & 35.1 & 35.2 & 36.3 & \\
\hline B M1 & 36.4 & 35.9 & 35.7 & 36.5 & 35.9 & 34.4 & 35.1 & 36.3 & 37.1 & \\
\hline C M1 & 33.7 & 36.6 & 37.1 & 36.2 & 37.2 & 35.4 & 35.5 & 35.7 & 36.0 & \\
\hline WA M1 & 36.5 & 36.0 & 36.4 & 35.2 & 36.0 & 35.5 & 35.4 & 35.6 & 35.6 & \\
\hline WB M1 & 36.5 & 36.2 & 36.5 & 35.2 & 36.0 & 35.6 & 35.5 & 35.6 & 35.6 & \\
\hline A M2 & 38.0 & 37.3 & 41.3 & 41.4 & 35.9 & 36.0 & 36.0 & 39.0 & 40.4 & \\
\hline B M2 & 38.4 & 37.5 & 40.8 & 43.4 & 40.0 & 36.0 & 36.3 & 40.0 & 42.0 & \\
\hline C M2 & 37.7 & 37.1 & 40.5 & 40.8 & 39.2 & 35.8 & 35.8 & 38.4 & 39.3 & \\
\hline WR M2 & & & 40.0 & 39.2 & 38.0 & 36.2 & 35.9 & 37.8 & 38.0 & \\
\hline WL M2 & & & 40.0 & 39.2 & 38.0 & 36.1 & 35.8 & 37.7 & 37.9 & 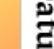 \\
\hline $\begin{array}{c}\text { OWR } \\
\text { M1 }\end{array}$ & 38.75 & 39.9 & 43.75 & 44.35 & 37.65 & 38.65 & 39.7 & 41.95 & 44 & 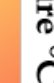 \\
\hline $\begin{array}{c}\text { OWL } \\
\text { M1 }\end{array}$ & 39.4 & 39.35 & 43 & 44.25 & 37.6 & 38.5 & 39.8 & 41.95 & 43.8 & \\
\hline $\mathrm{AO}$ & 42.0 & 43.0 & 49.0 & 52.0 & 41.0 & 39.5 & 46.0 & 49.0 & 57.0 & \\
\hline $\mathrm{BO}$ & 40.0 & 43.5 & 46.5 & 50.0 & 38.0 & 40.8 & 47.0 & 47.0 & 50.0 & 7 \\
\hline $\mathrm{CO}$ & 38.0 & 41.0 & 44.0 & 46.0 & 40.0 & 41.0 & 44.0 & 43.0 & 52.0 & \\
\hline $\mathrm{WO}$ & 37.0 & 39.9 & 42.5 & 43.0 & 38.0 & 39.0 & 41.0 & 41.0 & 42.0 & \\
\hline
\end{tabular}


Table 12. Surface temperatures of Room 1, Room 2, and the courtyard on 26 August and 1 September 2018.

\begin{tabular}{|c|c|c|c|c|c|c|c|c|c|}
\hline \multirow[b]{2}{*}{ Time } & \multicolumn{4}{|c|}{26 August } & \multicolumn{4}{|c|}{1 September } & \\
\hline & 12:00 p.m. & 1:00 p.m. & 2:00 p.m. & 3:00 p.m. & 12:00 p.m. & 1:00 p.m. & 2:00 p.m. & 3:00 p.m. & \\
\hline A M1 & 34.8 & 35.9 & 36.4 & 36.0 & 36.7 & 35.7 & 34.7 & 35.8 & \multirow{16}{*}{ 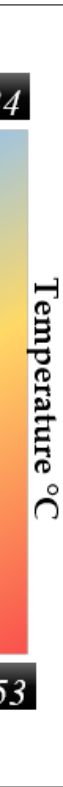 } \\
\hline B M1 & 34.7 & 36.4 & 36.7 & 37.3 & 37.6 & 36.0 & 35.9 & 37.5 & \\
\hline C M1 & 35.1 & 35.7 & 36.1 & 35.5 & 36.1 & 35.2 & 35.4 & 36.3 & \\
\hline WA M1 & 35.3 & 35.4 & 35.7 & 35.1 & 35.9 & 34.8 & 35.6 & 36.1 & \\
\hline WB M1 & 35.2 & 35.5 & 35.8 & 35.1 & 36.0 & 34.9 & 35.3 & 36.1 & \\
\hline A M2 & 35.5 & 36.3 & 37.3 & 39.2 & 37.2 & 36.9 & 39.9 & 40.5 & \\
\hline B M2 & 36.0 & 37.0 & 39.7 & 41.0 & 37.9 & 37.5 & 40.8 & 42.8 & \\
\hline C M2 & 35.4 & 36.1 & 37.1 & 38.5 & 36.7 & 36.5 & 39.0 & 39.7 & \\
\hline WR M2 & 35.8 & 35.8 & 36.2 & 37.2 & 36.3 & 35.7 & 38.6 & 38.3 & \\
\hline WL M2 & 35.5 & 35.7 & 36.3 & 37.1 & 36.2 & 35.8 & 38.6 & 38.1 & \\
\hline OWR M1 & 39.5 & 39.5 & 41 & 42 & 40.2 & 40.7 & 42 & 42.5 & \\
\hline OWL M1 & 39.5 & 39.3 & 41 & 41.8 & 40.6 & 41 & 41.7 & 41.5 & \\
\hline $\mathrm{AO}$ & 42.7 & 43.5 & 49.0 & 52.0 & 43.9 & 45.5 & 49.8 & 51.0 & \\
\hline $\mathrm{BO}$ & 41.0 & 42.0 & 44.0 & 50.0 & 42.0 & 43.8 & 47.0 & 48.0 & \\
\hline $\mathrm{CO}$ & 40.0 & 45.0 & 49.0 & 53.0 & 43.0 & 46.0 & 48.5 & 52.0 & \\
\hline $\mathrm{WO}$ & 39.0 & 39.5 & 39.3 & 41.0 & 38.5 & 39.0 & 41.0 & 40.7 & \\
\hline
\end{tabular}

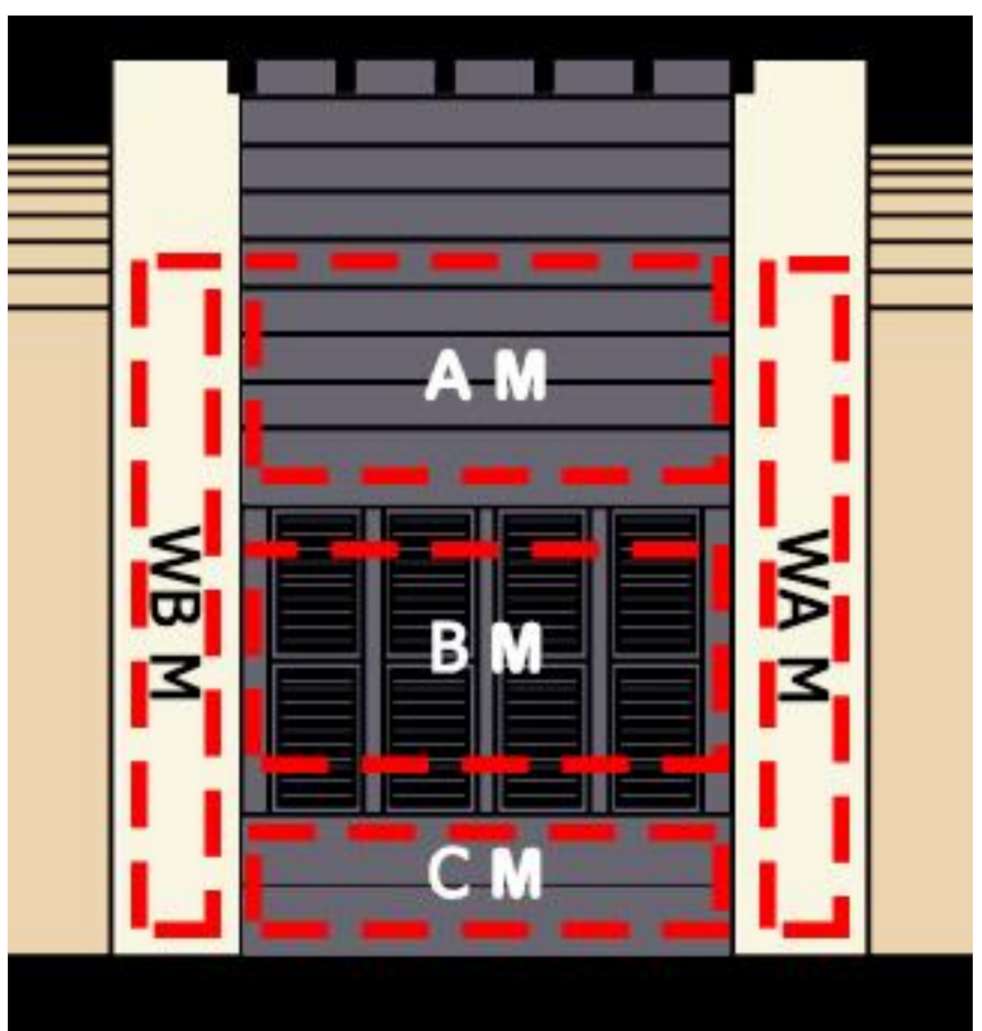

Figure 18. Interior measurement zones on the mashrabiya and abbreviated names.

The measurements were monitored on 4 August at about 1:00, 2:00, 3:00 p.m. also at noon on 5, 11, 18, 26 August and 1 September while monitored at about 6:00 p.m. on 13 August 2018. As shown in tables, surface temperature measurements increased and reach the highest values, usually at 3 p.m. while the entire facade was exposed to direct sunlight. 


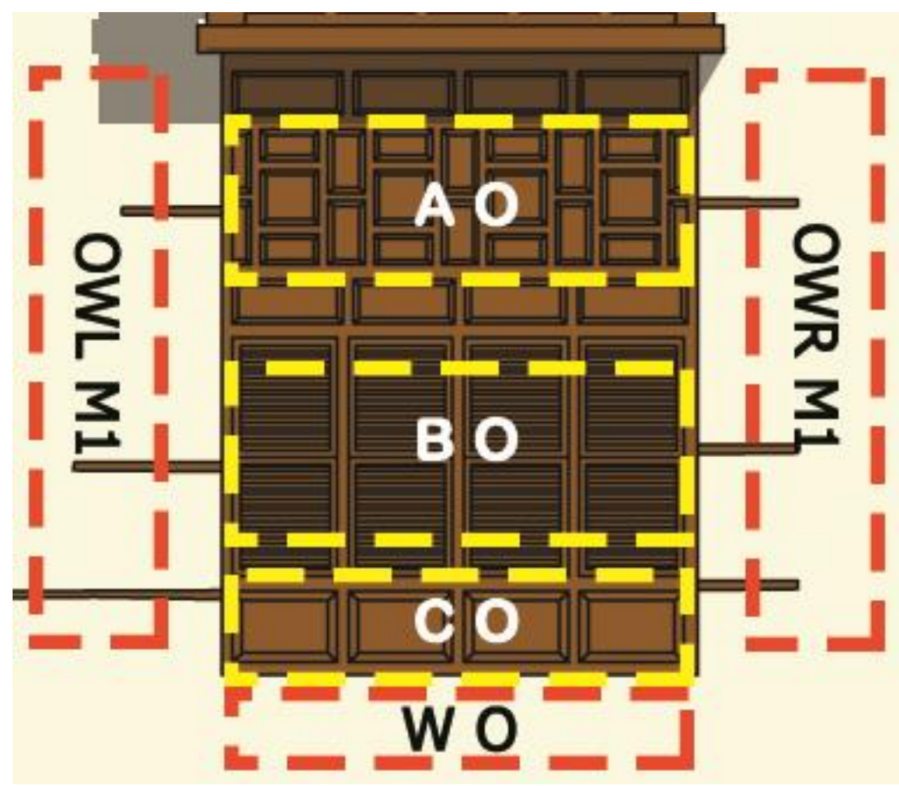

Figure 19. Measurement zones and abbreviated on the Mash1 from outside.

Moreover, Figure 20 shows the inside and outside average surface temperature in the middle area of the open mashrabiya and adjacent sidewalls during different days. It is important to clarify that western facade, which includes the exterior frames of the tested mashrabiyas, is not exposed to direct sunlight during the measurement times until about 12.30 p.m. $55{ }^{\circ} \mathrm{C}$ the maximum value was recorded on the external surface of the open mashrabiya at 3:00 p.m. on 4 August while the minimum was $34.3^{\circ} \mathrm{C}$ on the internal surface of mashrabiya at noon on 18 August. It can be noticed that surface temperatures of the exterior wall around the open mashrabiya absorbed less heat than the exterior surface of the mashrabiya indicating the benefit of the properties and colour of the plaster. Although the outside wall surface temperature was between $37^{\circ} \mathrm{C}$ to $45^{\circ} \mathrm{C}$, the heat gain into the rooms reduced by the building's thermal mass, where the temperatures range from 34.8 to $38.4^{\circ} \mathrm{C}$ on the internal surface of the wall. From Figure 20, it can be noticed that outside surface temperature of the wall and the mashrabiyas' external surface become equal during the sunset with a temperature around $38^{\circ} \mathrm{C}$.

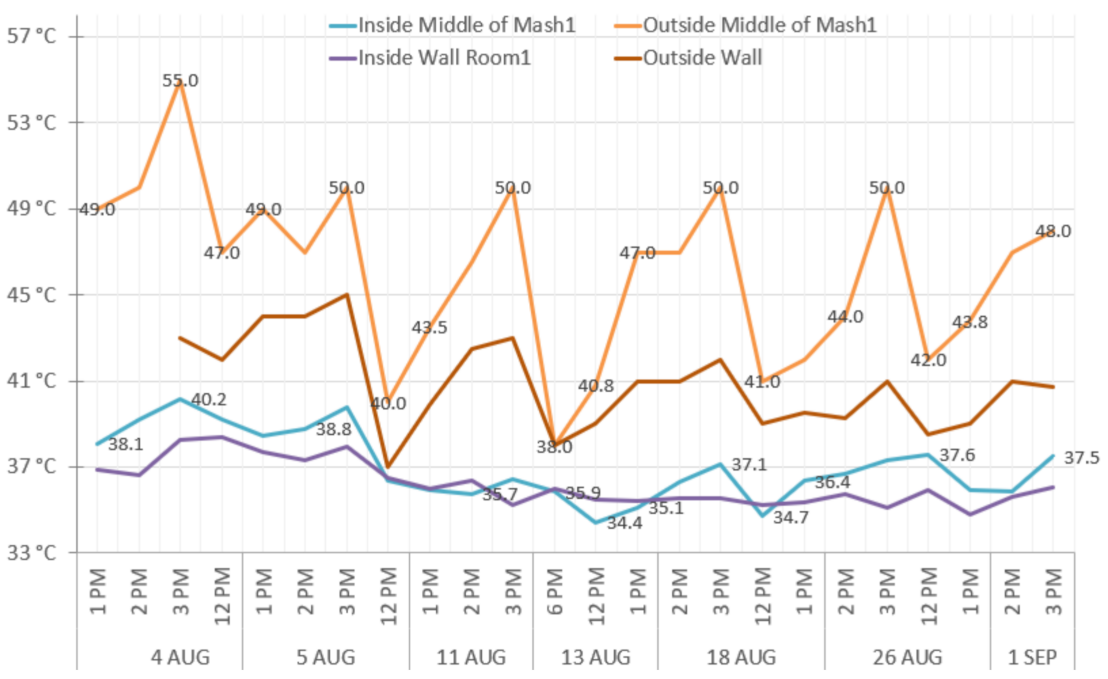

Figure 20. The surface temperatures of the open mashrabiya and wall surface inside and outside. 


\subsection{Thermal Comfort Assessment}

As part of the study of the performance of the mashrabiya, it was important to assess the impact of the mashrabiya on the indoor thermal comfort. Multiple methods and equations can be used to calculate the temperature of indoor comfort. Although ASHRAE 55 is considered as a master guide, the outdoor temperature averages of less than $10{ }^{\circ} \mathrm{C}$ or higher than $33.5^{\circ} \mathrm{C}$ are not taken into account. As the average outdoor temperature of this building was above this range, another method was used to evaluate the comfort temperature for passive buildings with the equation of Nicol and Humphreys [62] for estimate comfort temperature in free-running buildings as described below:

$$
T c=13.5+0.54 T o
$$

where $T c$ is the comfort temperature, and To is the monthly outdoor air temperature average. This study considered the average outdoor temperature measured during the experiment only, which was $36.2^{\circ} \mathrm{C}$. Therefore, the comfort temperature for this case is $33^{\circ} \mathrm{C}$, depending on the equation. It is worth pointing out that Pakistani participants felt comfortable at indoor temperatures around $33^{\circ} \mathrm{C}$ in the Nicol and Humphrey field study. The paper also stated that during the tests, the workers changed their clothing and used fans of air movement.

Figure 21 shows the rooms' level of comfort based on the calculated comfort temperatures and total measurements for both rooms. Each bar represents measurements of the complete room temperature for each day and the required degree to achieve comfort. The left-axis 0 value in the graph is equivalent to the calculated comfort temperature of $33^{\circ} \mathrm{C}$, means the values equal or above 0 considered within the comfort zone while the values below 0 have not achieved this.

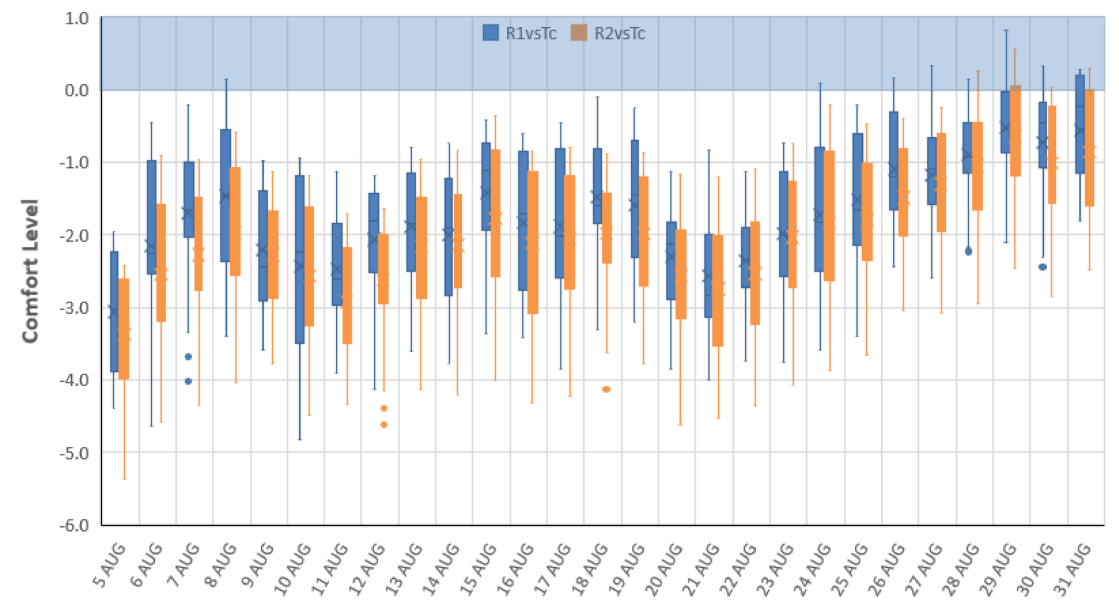

Figure 21. Rooms temperatures as compared to comfort temperature over the experiment days.

It is clear from the chart that the temperatures inside the R1 typically were closer to the level of comfort and better than R2 by 0.3 degrees on average. In any case, the decrease in outdoor temperatures to below $33^{\circ} \mathrm{C}$, contributed to improving the indoor temperatures and reaching the moderate temperature in some of the experiment days.

As shown in Figure 22, when the outdoor air temperature in Courtyard was below $32{ }^{\circ} \mathrm{C}$, both rooms achieved comfort between 4 and 8:30 a.m. on 29 August. Overall, the rooms were able to achieve comfort between 3 and 7 a.m. during experiment days with the effect of night ventilation and the lower outdoor temperatures. It is important to note that the experiment was conducted in the worst climate situations, where August represents the highest temperature average of the year. Consequently, the effect of opening up the mashrabiya or applying other passive cooling methods will often provide better impacts in the mild seasons. 


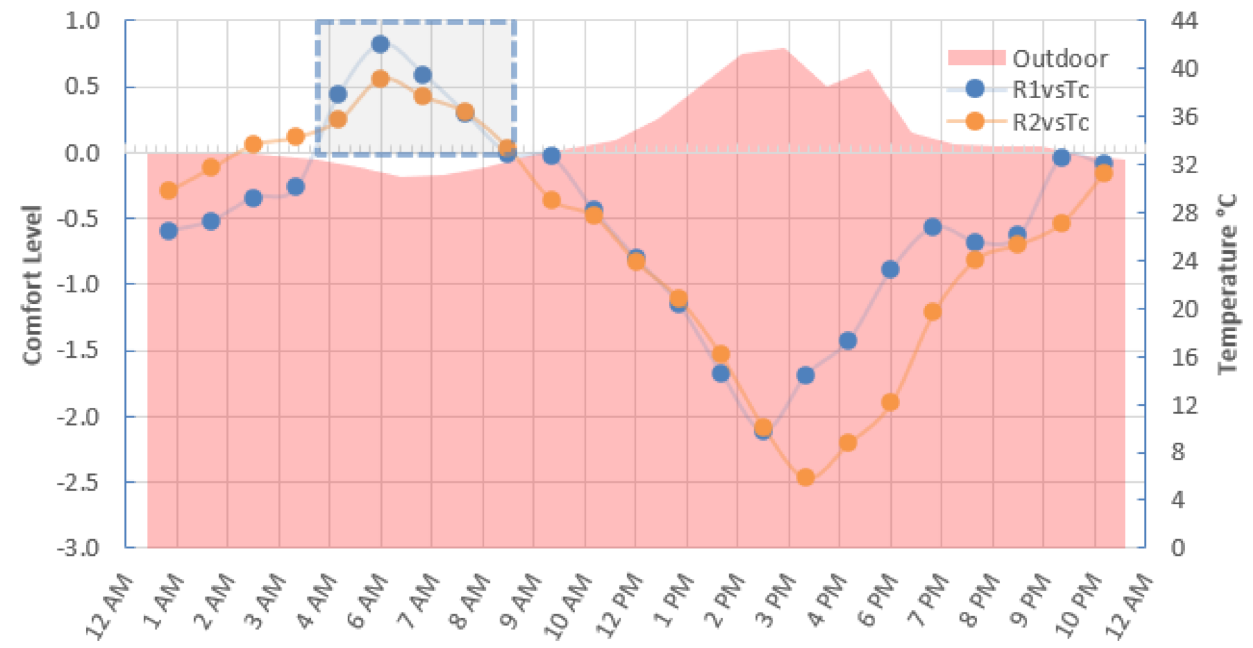

Figure 22. The hourly outdoor temperature and room temperature profiles of 29 August compared to the comfort level.

\section{Conclusions and Future Works}

This paper reviewed the mashrabiya through several aspects: definitions, history, design and structure, typology, and functions focusing on related research work and developments in hot climates. In a selected building in a hot climate, the impact of traditional mashrabiyas on the thermal indoor environment was evaluated. As reviewed, most studies tend to focus on either the history or development of mashrabiyas without testing or considering their actual performance and influence on the indoor thermal environment.

A case study was selected in the most plentiful region with mashrabiyas in Saudi Arabia "Historic Jeddah" to investigate and evaluate the efficiency of mashrabiyas on the indoor environment and comfort. The study demonstrated that open mashrabiyas allow daytime airflow, and thus enhance air movement and circulation in the room and reduce the indoor temperature by up to $2.4{ }^{\circ} \mathrm{C}$ in comparison with the closed mashrabiya. The evaluation of the indoor thermal comfort demonstrated that Room 1 typically were closer to the temperature comfort $33^{\circ} \mathrm{C}$ and better than Room 2 by 0.3 degrees on average. The open mashrabiya had positive effects on Room 1, but during such this warm outdoor weather, adding some passive cooling methods were being needed. The building envelope played an important role in delaying the heat flow into the rooms and maintaining the low fluctuating indoor air temperature ranging from $2.1^{\circ} \mathrm{C}$ to $4.2{ }^{\circ} \mathrm{C}$ compared to the high fluctuating temperatures of the air outdoor ranging from $9.4{ }^{\circ} \mathrm{C}$ to $16^{\circ} \mathrm{C}$.

It is also noteworthy that this field work has some limitations. The study assessed thermal comfort based only on the environmental factors without covering the personal factors. That was because no inhabitants were in the house during the tests, and the difficulty involving people in this type of experiment under such climatic and spatial conditions. The presented result of the indoor air velocity was measured at a specific point at each mashrabiya, and future work will be investigating more measurement points inside the rooms. For the outdoor air velocity, readings may be influenced by several factors such as the position of the anemometer, its elevation from the ground level, and some surrounding obstacles.

This study provides a review of existing studies on the traditional mashrabiya device and provides data on its performance in hot climates. Moreover, this knowledge can be applied to modern buildings by combining the mashrabiya concept with new solutions or improving its design according to the users' needs and modern building systems in hot climates. Additionally, it can be more effective to use this method in temperate climates and can lead to more thermal comfort periods. Furthermore, more studies and tests on mashrabiyas under different climatic conditions are required. In addition, the different 
strategies or materials can be incorporated with mashrabiyas with the aim of improving their thermal performance.

Author Contributions: Conceptualization, A.A.B.; methodology, A.A.B. and J.K.C.; software, A.A.B.; validation, A.A.B. and J.K.C.; formal analysis, A.A.B. and J.K.C.; investigation, A.A.B.; data curation, A.A.B.; writing—original draft preparation, A.A.B.; writing—review and editing, A.A.B., J.K.C. and A.S.K.; visualization, A.A.B. and J.K.C.; supervision, J.K.C.; funding acquisition, A.S.K. All authors have read and agreed to the published version of the manuscript.

Funding: This research was funded by Deanship of Scientific Research and Prince Khalid Al-Faisal Chair for Developing Makkah Al-Mukarramah and the Holy Places at Umm Al-Qura University grant number [DSRUQU.PKC-42-6].

Institutional Review Board Statement: Not applicable.

Informed Consent Statement: Not applicable.

Data Availability Statement: The data presented in this study are available on request from the corresponding author.

Acknowledgments: The authors would like to thank Deanship of Scientific Research and Prince Khalid Al-Faisal Chair for Developing Makkah Al-Mukarramah and the Holy Places at Umm Al-Qura University for the financial support. The authors gratefully acknowledge to Maha Oboud Baeshen, as one of the Baeshen house representatives, for allowing us to conduct the field experiment in the building. We are also grateful to Hanan $\mathrm{Al}$ Khatri for assistance and support with the equipment.

Conflicts of Interest: The authors declare that there is no conflict of interest.

\section{References}

1. Rafique, M.M.; Rehman, S.; Lashin, A.; Al Arifi, N. Analysis of a Solar Cooling System for Climatic Conditions of Five Different Cities of Saudi Arabia. Energies 2016, 9, 75. [CrossRef]

2. Shahzad, S.; Calautit, K.; Wei, S.; Tien, P.W.; Calautit, J.; Hughes, B. Analysis of the thermal comfort and energy performance of a thermal chair for open plan office. J. Sustain. Dev. Energy Water Environ. Syst. 2020, 8, 373-395. [CrossRef]

3. Bagasi, A.A.; Calautit, J.K. Experimental field study of the integration of passive and evaporative cooling techniques with Mashrabiya in hot climates. Energy Build. 2020, 225, 110325. [CrossRef]

4. Fathy, H. Natural Energy and Vernacular Architecture Principles and Examples with Reference to Hot Arid Climate; The University of Chicago Press: Chicago, IL, USA, 1986.

5. Saulles, T.D. Thermal Mass Explained. In The Concrete Centre; MPA The Concrete Centre: Camberley, Surrey, UK, 2015.

6. Baker, N.; Steemers, K. Energy and Environment in Architecture: A Technical Design Guide; Taylor \& Francis e-Library: London, UK, 2005.

7. Daemei, A.B.; Eghbali, S.R.; Khotbehsara, E.M. Bioclimatic design strategies: A guideline to enhance human thermal comfort in Cfa climate zones. J. Build. Eng. 2019, 25, 100758. [CrossRef]

8. Alharbi, A. Investigation of Sub-Wet Bulb Temperature Evaporative Cooling System for Cooling in Buildings; University of Nottingham: Nottingham, UK, 2014; Available online: http:/ / eprints.nottingham.ac.uk/27806/ (accessed on 1 February 2020).

9. Almerbati, N.; Ford, P.; Taki, A.; Dean, L. From Vernacular to Personalised and Sustainable. In Proceedings of the 48th International Conference of the Architectural Science Association, Genoa, Italy, 10-13 December 2014; pp. 479-490. Available online: http: / / anzasca.net/wp-content/uploads/2014/12/10_38_77.pdf (accessed on 15 June 2017).

10. Almerbati, N. Hybrid Heritage: An Investigation into the Viability of 3D-Printed Mashrabiya Window Screens for Bahraini Dwellings. Ph.D. Thesis, De Montfort University, Leicester, UK, 2016. Available online: http://hdl.handle.net/2086/12482 (accessed on 25 June 2017).

11. Almaany. Dictionary of Almaany. Available online: http:/ / www.almaany.com/ (accessed on 30 March 2017).

12. Al-Murahhem, F.M. Behind the Roshān: Visualising the Roshān as an Architectural Experience in Traditional Domestic Interiors; University of Brighton: Brighton, UK, 2008; Available online: https://research.brighton.ac.uk/en/studentTheses/behind-the-rosh\%C4\%81n (accessed on 10 December 2019).

13. Mohamed, J. The Traditional Arts and Crafts of Turnery or Mashrabiya. Master' Thesis, The State University of New Jersey, Piscataway, NJ, USA, 2015. Available online: http:/ / mals.camden.rutgers.edu/files/J_Mohamed.pdf (accessed on 10 May 2017).

14. Kamal, M.A. The morphology of traditional architecture of Jeddah: Climatic design and environmental sustainability. Glob. Built Environ. Rev. 2014, 9, 4-26.

15. Khan, S.M. Jeddah Old Houses. In Department of Scientific Research; King Abdulaziz City for Science and Technology: Riyadh, Saudi Arabia, 1986. 
16. Al-Shareef, F.M. Natural Light Control in Hadjazi Architecture: An Investigation of the Rowshan Performance by Computer Simulation. Ph.D. Thesis, University of Liverpool, Liverpool, UK, 1996. Available online: http://ethos.bl.uk/OrderDetails.do? uin=uk.bl.ethos.307640 (accessed on 14 February 2017).

17. Sudy, S. The Architectural Language of Park51 Understanding Cultural and Historical Connections; Washington State University: Washington, DC, USA, 2011; Available online: https://research.libraries.wsu.edu/xmlui/handle/2376/3584 (accessed on 30 February 2018).

18. Abdelgelil, N. A New Mashrabiyya for contemporary Cairo: Integrating traditional latticework from Islamic and Japanese cultures. J. Asian Archit. Build. Eng. 2006, 5, 37-44. [CrossRef]

19. Al-Murahhem, F. The mechanism of the rawāshīn: The case study of Makkah. WIT Trans. Ecol. Environ. 2010, 128, 13. [CrossRef]

20. Alitany, A.; Redondo, E.; Adas, A. The 3D Documentation of Projected Wooden Windows (The Roshans) in the Old City of Jeddah (Saudi Arabia) Using Image-based Techniques. In Proceedings of the ISPRS Ann. Photogramm. Remote Sens. Spatial Inf. Sci., II-5/W1. XXIV International CIPA Symposium, Strasbourg, France, 2-6 September 2013; pp. 7-12. Available online: http: / / www.isprs-ann-photogramm-remote-sens-spatial-inf-sci.net/II-5-W1/7/2013/isprsannals-II-5-W1-7-2013.pdf (accessed on 20 May 2018).

21. Talib, K. Shelter in Saudi Arabia; St. Martin's Press: New York, NY, USA, 1984; p. 144.

22. Germanà, M.L.; Alatawneh, B.; Reffat, R.M. Technological and behavioral aspects of perforated building envelopes in the Mediterranean region. In Proceedings of the 10th Conference on Advanced Building Skins, Bern, Switzerland, 4 November 2015; pp. 846-854. Available online: https://www.researchgate.net/profile/Maria_Luisa_Germana/publication/283732169_ Technological_and_behavioral_aspects_of_perforated_building_envelopes_in_the_Mediterranean_region/links/564623bb0 8ae54697fb9d81b.pdf (accessed on 9 November 2018).

23. Alitany, A.; Baik, A.; Boehm, J.; Robson, S. Jeddah historical building information modeling “JHBIM" Old Jeddah-Saudi Arabia. In Proceedings of the International Archives of the Photogrammetry, Remote Sensing and Spatial Information Sciences-ISPRS Archives, Strasbourg, France, 2-6 September 2013; pp. 73-78. Available online: https:/ / www.int-arch-photogramm-remote-sensspatial-inf-sci.net/XL-5-W2/73/2013/. (accessed on 20 June 2018).

24. Batterjee, S.A. Performance of Shading Device Inspired by Traditional Hejazi Houses in Jeddah Saudi Arabia; The British University in Dubai: Dubai, UAE, 2010; Available online: http:/ /bspace.buid.ac.ae/handle/1234/142 (accessed on 23 May 2017).

25. Maghrabi, A.A. Airflow Characteristics of Modulated Louvered Windows with Reference to the Rowshan of Jeddah, Saudi Arabia. Ph.D. Thesis, University of Sheffield, Sheffield, UK, 2000. Available online: http://etheses.whiterose.ac.uk/id/eprint/14623 (accessed on 17 July 2017).

26. Salloum, A. El-Rawashin of Jeddah, Saudi Arabia. In Proceedings of the Second International PLEA Conference, Crete, Greece, 28 June-1 July 1983; pp. 245-252.

27. Aljofi, E. The potentiality of reflected sunlight through Rawshan screens. In Proceedings of the International Conference "Passive and Low Energy Cooling for the Built Environment", Santorini, Greece, May 2005; pp. 817-822. Available online: http:/ / www.inive.org/members_area/medias/pdf/inive/palenc/2005/aljofi.pdf (accessed on 2 January 2017).

28. Greenlaw, J.-P. The Coral Buildings of Suakin; Oriel Press: Stocksfield, UK, 1976.

29. Adas, A.A. Wooden Bay Window (Rowshan) Conservation in Saudi-Hejazi Heritage Buildings. In Proceedings of the ISPRSInternational Archives of the Photogrammetry, Remote Sensing and Spatial Information Sciences, Strasbourg, France; pp. 7-11. Available online: http:/ / www.int-arch-photogramm-remote-sens-spatial-inf-sci.net/XL-5-W2/7/2013/isprsarchives-XL-5W2-7-2013.pdf (accessed on 8 January 2020).

30. Hariri, M. Design of Rowshan and its importance to the dwelling. J. Umm-Al-Qura Univ. 1992, 3, $175-237$.

31. Naciri, N. Sustainable features of the Vernacular Architecture: A Case Study of Climatic Controls in the Hot-Arid regions of the Middle Eastern and North African Regions. 2007, p. 15. Available online: https:/ / www.solaripedia.com/files/488.pdf (accessed on 5 September 2017).

32. Sabry, E.; Dwidar, S. Contemporary Islamic Architecture towards preserving Islamic heritage. ResearchGate 2015. [CrossRef]

33. Algburi, O.; Beyhan, F. Cooling Load Reduction in a Single-Family House, an Energy-Efficient Approach. Gazi Univ. J. Sci. 2019, 32, 385-400.

34. Al-Ban, A.Z.G. Architecture and Cultural Identity in the Traditional Homes of Jeddah. Ph.D. Thesis, University of Colorado, Denver, CO, USA, 2016. Available online: https://search.proquest.com/openview/bf247bf137581eda868bab9ca90181d5/1?pqorigsite $=$ gscholar\&cbl=18750\&diss=y (accessed on 11 November 2019).

35. Ashour, A.F. Islamic Architectural Heritage: Mashrabiya. WIT Trans. Built Environ. 2018, 177, 245-253. [CrossRef]

36. Otusanya, O.P.; Ajwang, P.; Ondimu, S.N. Reducing Cooling Demands in Sub-Saharan Africa: A Study on The Thermal Performance of Passive Cooling Methods in Enclosed Spaces. J. Sustain. Dev. Energy Water Environ. Syst. 2020. [CrossRef]

37. Abdelkader, R.; Park, J.-H. Sustainable Building Façades: Modern Usages of The Traditional Mashrabiya. Open House Int. 2018, 43, 69-76. [CrossRef]

38. AL-Dossary, A.M.; Kim, D.D. A Study of Design Variables in Daylight and Energy Performance in Residential Buildings under Hot Climates. Energies 2020, 13, 5836. [CrossRef]

39. Alothman, H. An Evaluative and Critical Study of Mashrabiya. In Contemporary Architecture; LAP LAMBERT Academic Publishing: Koln, Germany, 2017; Available online: http:/ / docs.neu.edu.tr/library/6505208522.pdf (accessed on 19 April 2019). 
40. Al-Hashimi, A.A.K.; Semidor, C. Virtual Study of the Day-lighting Performance of Rawshan in Residential Buildings of Jeddah. SB13 Dubai Pap 2013, 8, 689-696.

41. Alwetaishi, M.; Balabel, A.; Abdelhafiz, A.; Issa, U.; Sharaky, I.; Shamseldin, A.; Al-Surf, M.; Al-Harthi, M.; Gadi, M. User Thermal Comfort in Historic Buildings: Evaluation of the Potential of Thermal Mass, Orientation, Evaporative Cooling and Ventilation. Sustainability 2020, 12, 9672. [CrossRef]

42. Benedetti, C.; Baratieri, M.; Leone, G.; Mimmo, T.; Paglialonga, G. Wood technology for passive cooling. In Proceedings of the 11th World Conference on Timber Engineering, Trentino, Italy, 20-24 June 2010; pp. 20-24.

43. Samuels, W. Performance and Permeability: An Investigation of the Mashrabiya for Use within the Gibson Desert. Master's Thsis, Victoria University of Wellington, Wellington, New Zealand, 2011. Available online: http:/ / support.sbcindustry.com/ Archive/2010/june/Paper_386.pdf (accessed on 17 January 2018).

44. Karamata, B.; Giovannini, L.; Verso, V.R.L.; Andersen, M. Concept, Design and Performance of a Shape Variable Mashrabiya as a Shading and Daylighting System for Arid Climates. In Proceedings of the 30th International Passive and Low Energy Architecture Conference (PLEA 2014), Ahmedabad, India, 16-18 December 2014; pp. 344-351. Available online: http:/ /infoscience.epfl.ch/ record/206749 (accessed on 25 January 2020).

45. Giovannini, L.; Verso, V.R.L.; Karamata, B.; Andersen, M. Lighting and Energy Performance of an Adaptive Shading and Daylighting System for Arid Climates. Energy Procedia 2015, 78, 370-375. [CrossRef]

46. Sabry, H.; Sherif, A.; Gadelhak, M.; Aly, M. Balancing the daylighting and energy performance of solar screens in residential desert buildings: Examination of screen axial rotation and opening aspect ratio. Sol. Energy 2014, 103, 364-377. [CrossRef]

47. Khadra, A.A.; Chalfoun, N. Development of an integrated passive cooling façade technology for office buildings in hot arid regions. WIT Trans. Ecol. Environ. 2014, 190, 13. [CrossRef]

48. Batool, A. Quantifying Environmental Performance of Jali Screen Façadesfor Contemporary Buildings in Lahore, Pakistan. Master's Thesis, University of Oregon, Eugene, OR, USA, 2014.

49. Di Turi, S.; Ruggiero, F. Re-interpretation of an ancient passive cooling strategy: A new system of wooden lattice openings. Energy Procedia 2017, 126, 289-296. [CrossRef]

50. Alrashed, F.; Asif, M.; Burek, S. The Role of Vernacular Construction Techniques and Materials for Developing Zero-Energy Homes in Various Desert Climates. Buildings 2017, 7, 17. [CrossRef]

51. Taleb, H.M.; Antony, A.G. Assessing different glazing to achieve better lighting performance of office buildings in the United Arab Emirates (UAE). J. Build. Eng. 2020, 28, 101034. [CrossRef]

52. Schiano-Phan, R. The Development of Passive Downdraught Evaporative Cooling Systems Using Porous Ceramic Evaporators and Their Application in Residential Buildings. In Proceedings of the 28th International Conference on Passive and Low Energy Architecture, PLEA2004, Eindhoven, The Netherlands, 1 September 2004; pp. 9-12. Available online: https: / / pdfs.semanticscholar.org/9dc0/8529e5c8142a9fab7b85c34505cecd8f6db9.pdf?_ga=2.190489387.1229423698.157113747 9-515657236.1571137479 (accessed on 5 January 2019).

53. Cain, A.; Afshar, F.; Norton, J.; Daraie, M.-R. Traditional Cooling Systems in the Third World. Ecologist 1976, 6, 60-64.

54. Rael, R.; Fratello, V.S. Cool Brick. Available online: http://www.emergingobjects.com/projects/cool-brick/ (accessed on 10 December 2019).

55. Rosa, S.-P. Environmental retrofit: Building integrated passive cooling in housing. Archit. Res. Q 2010, 14, 139-151. [CrossRef]

56. Nermine, A.G.M.; Nancy, M.B. Simulated comparative investigation of the daylight and airflow of the conventional Egyptian shutter 'sheesh' and a proposed latticework device 'new mashrabiyya'. Indoor and Built Environment; 2014; 24, pp. 583-596. [CrossRef]

57. Ahmed, A.F. Using Ecooler technique to enhance thermal comfort in hot desert arid climate in Egypt, ed: Research Gate, November 2015. Available online: https://www.researchgate.net/publication/312041119_Using_Ecooler_technique_to_enhance_thermal_ comfort_in_hot_desert_arid_climate_in_Egypt (accessed on 6 February 2020).

58. Headley, D.; Almerbati, N.; Ford, P.; Taki, A. From Research to Practice: Exploring 3D Printing in Production of Architectural Mashrabiya. In Proceedings of the 49th International Conference of the Architectural Science Association, Melbourne, Austrailia, 2-4 December 2015; Available online: https://www.researchgate.net/profile/Nehal_Almerbati/publication/295830447_From_ research_to_practice_exploring_3D_printing_in_production_of_architectural_Mashrabiya/links/56cdc8d708ae85c8233e6bb5 .pdf) (accessed on 10 February 2019).

59. Alsharif, A.M. Towards Islamic Architecture: An Attempt to Understand Architecture from an Islamic Perspective. Master's Thesis, Savannah College of Art and Design, Savannah, GA, USA, June 2016. Available online: http:/ / ecollections.scad.edu/iii/ cpro/DigitalItemViewPage.external;jsessionid=503FD8C0DFA8F71832D4C67D7DCE7C07?lang=eng\&sp=1003432\&sp=T\&sp= $1 \&$ suite $=$ de (accessed on 18 November 2020).

60. Elkhatieb, M.; Sharples, S. Climate Adaptive Building Shells for Office Buildings in Egypt: A Parametric and Algorithmic Daylight Tool. In Proceedings of the SBE16 Dubai, Dubai, UAE, 17-19 January 2016; pp. 1-8. Available online: http://livrepository. liverpool.ac.uk/id/eprint/2047779 (accessed on 14 November 2020).

61. ASHRAE. ANSI/ASHRAE Standard 55. In Thermal Environmental Conditions for Human Occupancy; ASHRAE: Atlanta, GA, USA, 2010.

62. Nicol, J.F.; Humphreys, M.A. Adaptive thermal comfort and sustainable thermal standards for buildings. Energy Build. 2002, 34, 563-572. [CrossRef] 